Prepared in cooperation with the U.S. Fish and Wildlife Service and North Dakota State University

\title{
Climate Change and Prairie Pothole Wetlands-Mitigating Water-Level and Hydroperiod Effects Through Upland Management
}

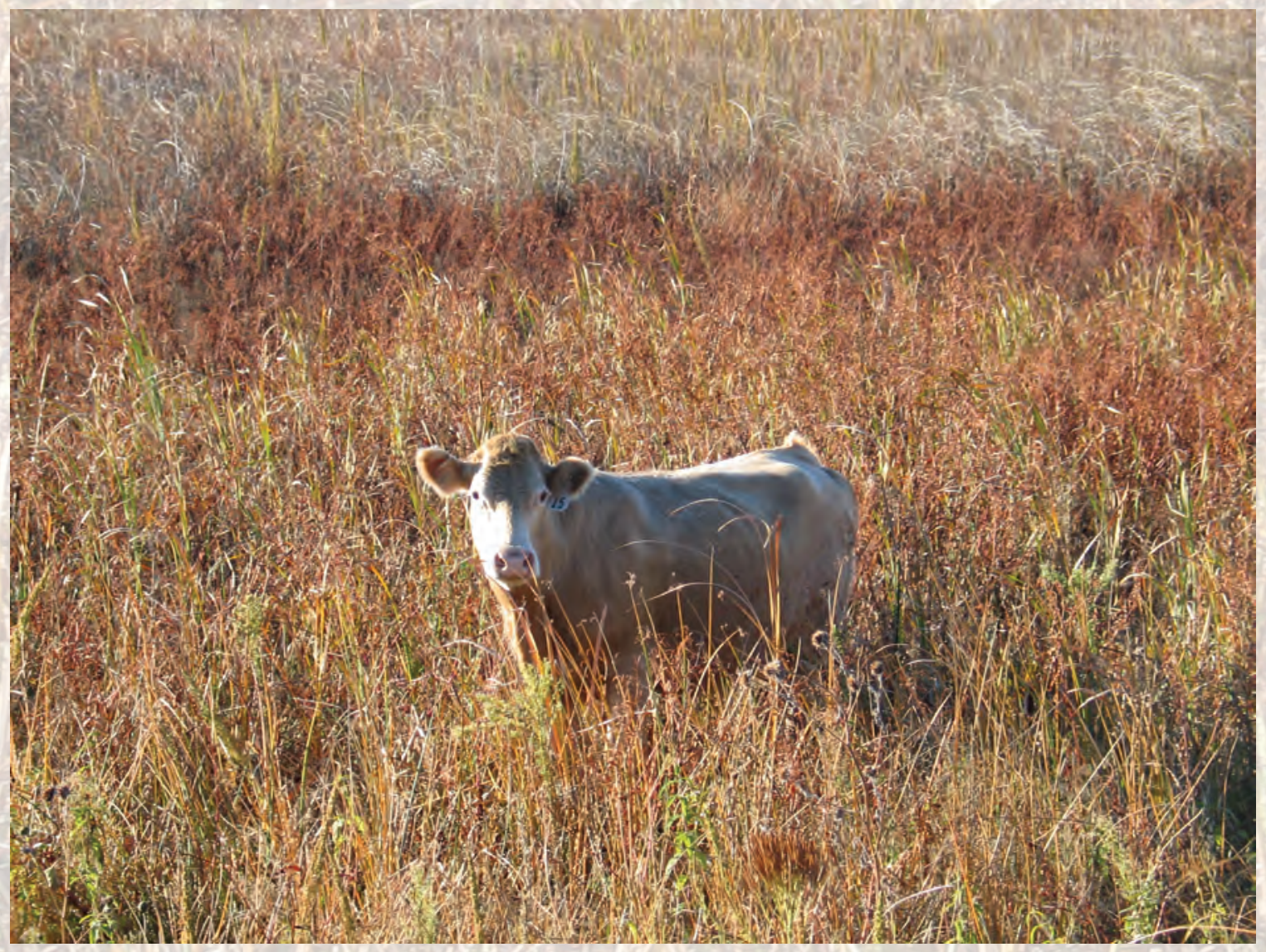

Scientific Investigations Report 2015-5004 
Cover. A cow standing in a dry wetland at Lacreek National Wildlife Refuge in South Dakota. Photograph by David M. Mushet, U.S. Geological Survey, October 13, 2004. 


\section{Climate Change and Prairie Pothole Wetlands-Mitigating Water-Level and Hydroperiod Effects Through Upland Management}

By David A. Renton, David M. Mushet, and Edward S. DeKeyser

Prepared in cooperation with the U.S. Fish and Wildlife Service and North Dakota State University

Scientific Investigations Report 2015-5004 


\title{
U.S. Department of the Interior SALLY JEWELL, Secretary
}

\section{U.S. Geological Survey Suzette M. Kimball, Acting Director}

\author{
U.S. Geological Survey, Reston, Virginia: 2015
}

For more information on the USGS - the Federal source for science about the Earth, its natural and living resources, natural hazards, and the environment, visit http://www.usgs.gov or call 1-888-ASK-USGS.

For an overview of USGS information products, including maps, imagery, and publications, visit http://www.usgs.gov/pubprod

To order this and other USGS information products, visit http://store.usgs.gov

Any use of trade, firm, or product names is for descriptive purposes only and does not imply endorsement by the U.S. Government.

Although this information product, for the most part, is in the public domain, it also may contain copyrighted materials as noted in the text. Permission to reproduce copyrighted items must be secured from the copyright owner.

Suggested citation:

Renton, D.A., Mushet, D.M., and DeKeyser, E.S., 2015, Climate change and prairie pothole wetlands-Mitigating water-level and hydroperiod effects through upland management: U.S. Geological Survey Scientific Investigations Report 2015-5004, 21 p., http://dx.doi.org/10.3133/sir20155004.

ISSN 2328-0328 (online) ISSN 2328-031X (print) ISBN 978-1-4113-3902-6 


\section{Contents}

Abstract
Introduction
Climate Change Effects on Prairie Pothole Wetland Hydrology
Modeling Wetland Response to Climate Change
Monitoring Wetland Response to Climate Change
Grassland Grazing
Grassland Burning
Snow Management




\section{Figures}

1. Map showing extent of Prairie Pothole Region in North America .......................................

2. Generalized view of a prairie pothole wetland water budget...........................................2

3. Graphs showing shifts in the cover cycle index for the Prairie Pothole Region under several climate change scenarios.

4. Graph showing frequency of hydroperiod calculated for a seasonal prairie pothole wetland

6. Graphs showing May ponds and waterfowl populations under different scenarios of temperature and precipitation.

5. Graph showing estimated May breeding duck population and the average May Palmer Drought Severity Index during 1955-96 for the north-central United States........7

7. Graph showing infiltration rates from 50-minute simulated rainfall event for burned and unburned sites

8. Diagram showing equilibrium drift geometry for a horizontal slat fence with 50 percent porosity placed on level terrain

9. Diagram showing cross section of 1:30 model livestock pond 15

\section{Tables}

1. Projected percentage of wet basins per year in the Prairie Pothole Region under differing climate change scenarios.

2. May Palmer Drought Severity Index, May ponds, and May duck populations for historical conditions based on Geophysical Fluid Dynamics Laboratory 0-flux and United Kingdom Hadley Center general circulation models

3. Precipitation and runoff for differentially grazed watersheds.

4. Mean wetland water levels for each land-use type under several climate change scenarios 


\section{Conversion Factors}

Inch/Pound to International System of Units

\begin{tabular}{lcc}
\hline & Multiply & To obtain \\
\hline inch (in.) & Length & \\
\hline & 2.54 & centimeter $(\mathrm{cm})$ \\
\hline acre & Area & \\
\hline & 0.4047 & hectare (ha) \\
\hline pound, avoirdupois (lb) & Mass & \\
\hline
\end{tabular}

International System of Units to Inch/Pound

\begin{tabular}{lll}
\hline \multicolumn{1}{c}{ Multiply } & By & \multicolumn{1}{c}{ To obtain } \\
\hline centimeter $(\mathrm{cm})$ & Length & \\
millimeter $(\mathrm{mm})$ & 0.3937 & inch (in.) \\
meter $(\mathrm{m})$ & 0.03937 & inch (in.) \\
kilometer $(\mathrm{km})$ & 3.281 & foot (ft) \\
\hline & 0.6214 & mile (mi) \\
\hline hectare $($ ha) & Area & square mile $\left(\mathrm{mi}^{2}\right)$ \\
square kilometer $\left(\mathrm{km}^{2}\right)$ & 0.003861 & square mile $\left(\mathrm{mi}^{2}\right)$ \\
\hline & 0.3861 & \\
\hline cubic meter per year $\left(\mathrm{m}^{3} / \mathrm{yr}\right)$ & Flow rate & acre-foot per year $(\mathrm{acre}-\mathrm{ft} / \mathrm{yr})$ \\
kilometer per hour $(\mathrm{km} / \mathrm{h})$ & 0.000811 & mile per hour $(\mathrm{mi} / \mathrm{h})$ \\
\hline
\end{tabular}

Temperature in degrees Celsius $\left({ }^{\circ} \mathrm{C}\right)$ may be converted to degrees Fahrenheit $\left({ }^{\circ} \mathrm{F}\right)$ as follows: ${ }^{\circ} \mathrm{F}=\left(1.8 \times{ }^{\circ} \mathrm{C}\right)+32$

Temperature in degrees Fahrenheit $\left({ }^{\circ} \mathrm{F}\right)$ may be converted to degrees Celsius $\left({ }^{\circ} \mathrm{C}\right)$ as follows: ${ }^{\circ} \mathrm{C}=\left({ }^{\circ} \mathrm{F}-32\right) / 1.8$ 



\title{
Climate Change and Prairie Pothole Wetlands-Mitigating Water-Level and Hydroperiod Effects Through Upland Management
}

\author{
By David A. Renton', David M. Mushet' ${ }^{1}$, and Edward S. DeKeyser ${ }^{2}$
}

\section{Abstract}

Prairie pothole wetlands offer crucial habitat for North America's waterfowl populations. The wetlands also support an abundance of other species and provide ecological services valued by society. The hydrology of prairie pothole wetlands is dependent on atmospheric interactions. Therefore, changes to the region's climate can have profound effects on wetland hydrology. The relevant literature related to climate change and upland management effects on prairie pothole wetland water levels and hydroperiods was reviewed. Climate change is widely expected to affect water levels and hydroperiods of prairie pothole wetlands, as well as the biota and ecological services that the wetlands support. In general, hydrologic model projections that incorporate future climate change scenarios forecast lower water levels in prairie pothole wetlands and longer periods spent in a dry condition, despite potential increases in precipitation. However, the extreme natural variability in climate and hydrology of prairie pothole wetlands necessitates caution when interpreting model results. Recent changes in weather patterns throughout much of the Prairie Pothole Region have been in increased precipitation that results in increased water inputs to wetlands above losses associated with warmer temperatures. However, observed precipitation increases are within the range of natural climate variability and therefore, may not persist. Identifying management techniques with the potential to affect water inputs to prairie pothole wetlands would provide increased options for managers when dealing with the uncertainties associated with a changing climate. Several grassland management techniques (for example, grazing and burning) have the potential to affect water levels and hydroperiods of prairie pothole by affecting infiltration, evapotranspiration, and snow deposition.

\footnotetext{
${ }^{1}$ U.S. Geological Survey.
}

${ }^{2}$ North Dakota State University, School of Natural Resource Sciences.

\section{Introduction}

The Prairie Pothole Region (PPR) encompasses approximately 777,000 square kilometers (Smith and others, 1964) ranging from central Alberta in Canada southward to northcentral Iowa in the United States (fig. 1). The PPR landscape is dotted with 5-8 million wetlands commonly called "potholes" or "sloughs" that were formed as Pleistocene Epoch glaciers receded around 12,000 years ago (Dyke and Prest, 1987). The wetlands formed where water accumulated in small depressions in a landscape that is underlain by low-permeability glacial till.

The climate of the PPR is highly dynamic and characterized by a west-to-east precipitation gradient, being drier in the west and wetter in the east (300-900 millimeters per year) and a north to south temperature gradient, being colder in the north and warmer in the south (average of 1-10 degrees Celsius $\left[{ }^{\circ} \mathrm{C}\right]$; Millett and others, 2009). Across the temperature gradient, the PPR also experiences great seasonal changes. Temperatures below $-40{ }^{\circ} \mathrm{C}$ in the winter and above $40^{\circ} \mathrm{C}$ in the summer are not uncommon. Wind speeds in the PPR often exceed 60 kilometers per hour, greatly influencing evapotranspiration rates in the summer and movement of snow in the winter. Furthermore, the PPR climate fluctuates between wet and dry periods, with periods of deluge often being followed by drought (Winter and Rosenberry, 1998). Overall, the great climate variability is a key feature affecting PPR wetlands and the biotic communities that the wetlands support (Euliss and others, 1999).

The dynamic nature of the PPR climate creates wetlands of differing water permanence. Wetland types have been prescribed on the basis of water permanence and diagnostic vegetation that forms zones reflective of differing water depths (Stewart and Kantrud, 1971). Temporary wetlands are typically wet for a few weeks after snowmelt or after a heavy rainstorm and have a plant community that consists primarily of wet-meadow vegetation located in the central, deepest zone of the wetlands. Seasonal wetlands usually are dry by midsummer and have shallow-marsh vegetation that dominates the central zone of the wetlands. Semipermanent wetlands frequently have water for the entire growing season 

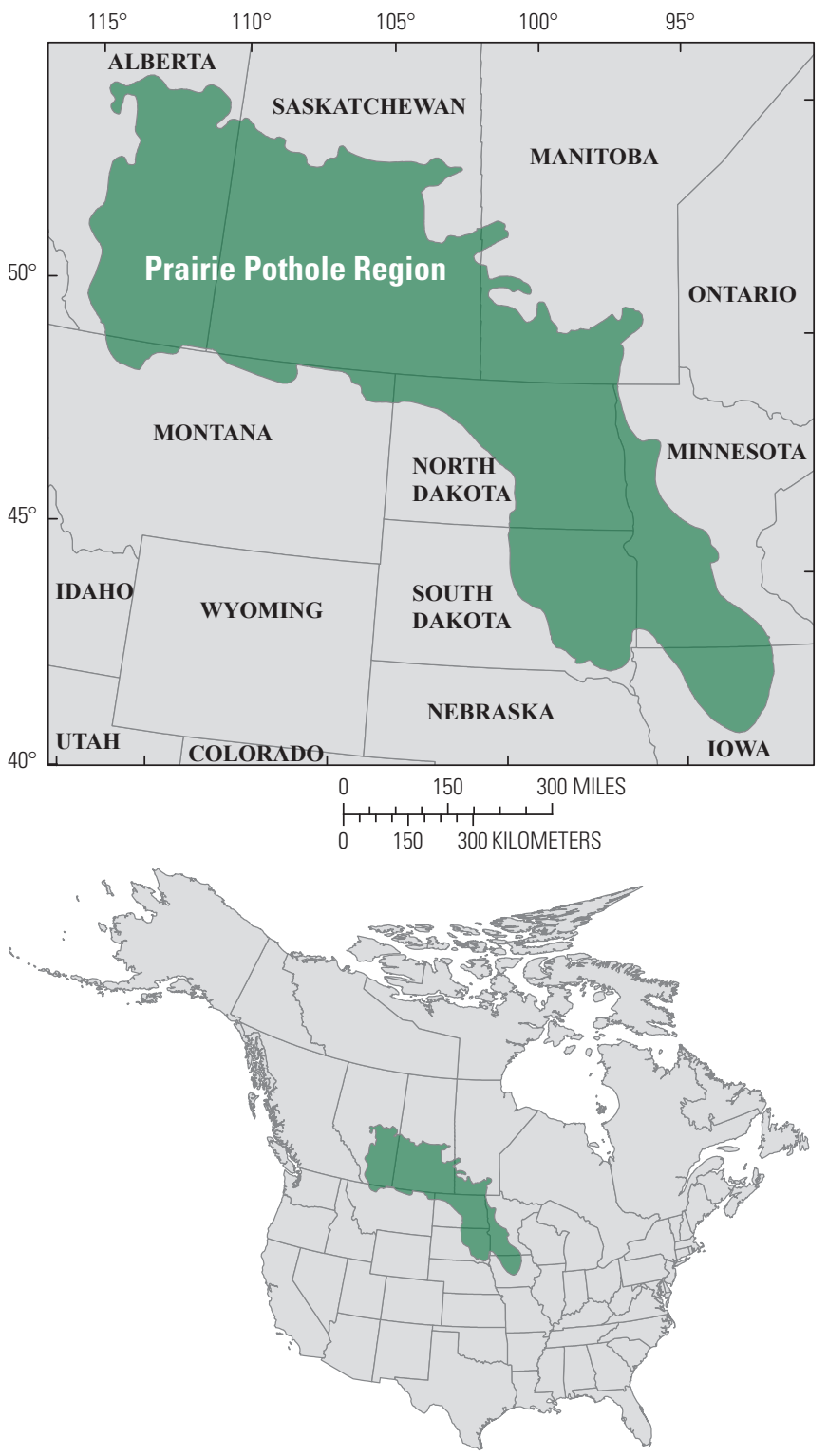

Figure 1. Extent of Prairie Pothole Region in North America.

but may be dry during years of drought. Deep-marsh emergent and (or) submergent vegetation characterizes the central zone of semipermanent wetlands. Groups of different classes of wetlands form what is known as wetland complexes (Johnson and others, 2010). However, a working definition of a "wetland complex" has yet to be defined.

Wetlands in the PPR are host to a variety of wildlife including invertebrates, fish, amphibians, reptiles, small mammals, and birds; most notably waterfowl. Many other groups of animals have been directly and indirectly affected by wetlands (Kantrud and others, 1989); however, waterfowl have received the most attention because of their monetary and sporting value and their high degree of dependence on wetlands of the PPR. The PPR consists of only 10 percent of the total waterfowl breeding habitat area in North America, yet it produces 50-80 percent of North America's waterfowl populations (Batt and others, 1989). Thus, the
PPR is a recreational hotspot for waterfowl hunters. The PPR also produces the birds that support recreational hunting opportunities along flyways and in overwintering areas outside of the PPR. Prairie pothole wetlands also provide a wide variety of benefits other than serving as aquatic habitats in a terrestrial landscape. The benefits include sediment entrapment, water-quality improvement, flood control, groundwater recharge, recreation, and aesthetic values (Kantrud and others, 1989; Leitch, 1996; Gleason and others, 2008; Werner and others, 2013).

Despite the benefits that wetlands provide, they have historically been seen as a nuisance and a hindrance to agricultural production (Leitch, 1989). This misunderstanding has led to many PPR wetlands being filled, drained, or otherwise manipulated to facilitate crop production. In the conterminous United States it has been estimated that 60-65 percent of PPR wetlands have been lost (Dahl, 2014). Remaining prairie pothole wetlands are sensitive to changes in climate because of their dependence on atmospheric interactions (Winter and Rosenberry, 1998). Prairie potholes receive water through direct precipitation, runoff, and snowmelt. The potholes lose water primarily through evapotranspiration, which varies temporally and geographically in the PPR and is typically greater than inputs (fig. 2). Climate change can not only alter water inputs, but associated increased temperatures can enhance evapotranspiration rates as well. Interactions with groundwater often play a small role in wetland water budgets but can have significant effects on water chemistry (LaBaugh and others, 1998; Swanson and others, 2003). The net annual water budget of a prairie pothole wetland ranges from -10 to -60 centimeters (cm; Winter, 1989). Therefore, any change to water inputs from a changing climate has the potential to greatly affect water levels and hydroperiods (the period of time a wetland contains ponded water) of prairie pothole wetlands. However, changes in land use and management can alter evapotranspiration, infiltration, runoff, and snow dispersal patterns within a watershed, potentially providing a mechanism to mitigate climate change effects.

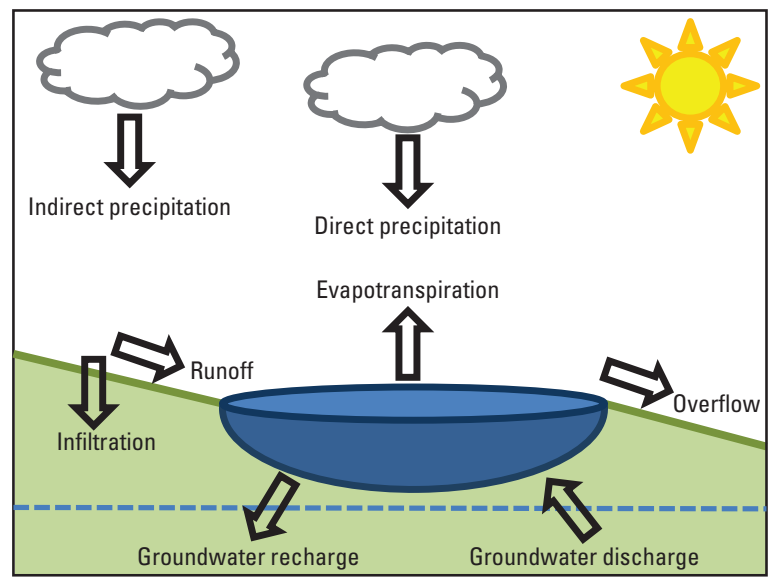

Figure 2. Generalized view of a prairie pothole wetland water budget. 
The purpose of this study was to (1) summarize current (2014) research on the effects of upland management techniques on prairie pothole wetland water levels and hydroperiods and (2) identify potential upland management techniques that may be used to offset effects of climate change on valued wetland ecosystems. Accurate estimates of climate change are needed in order to estimate effects on wetland dynamics in the PPR; thus, the current (2014) literature on regional projections of climate change also was reviewed during the study.

\section{Climate Change Effects on Prairie Pothole Wetland Hydrology}

Temperature of the Earth's atmosphere is predicted to increase between 1.5 and $4{ }^{\circ} \mathrm{C}$ by 2100 accompanied by an increase in total precipitation (Intergovernmental Panel on Climate Change, 2013). The increased patterns are anticipated to differ among regions. Temperatures are likely to increase between 3.7 and $6.1{ }^{\circ} \mathrm{C}$ in the Great Plains by the 2090s (Ojima and others, 2002). However, a greater warming trend is expected in the winter and spring compared to the summer or fall. Also, the number of frost-free days is expected to increase for the region, resulting in an earlier advancement of spring conditions (Meehl and others, 2004; Johnson and others, 2010). Precipitation is more difficult to model because of the great variability of the region. Nevertheless, precipitation is expected to range from -5 to +10 percent of current conditions (Intergovernmental Panel on Climate Change, 2013). The west to east precipitation gradient characteristic of the PPR may steepen or shift eastward under future climate scenarios (Johnson and others, 2005, 2010). However, gains in precipitation will likely be offset by increased evapotranspiration rates resulting from increased temperatures and evaporative demands (Ballard and others, 2014). Additionally, the frequency and severity of drought and deluge conditions are expected to intensify under an increased greenhouse gas climate (Ojima and others, 2002; Johnson and others, 2004; Intergovernmental Panel on Climate Change, 2013).

Some of the changes associated with a globally changing climate have already been detected in the PPR. Air temperatures in the PPR have risen by $1{ }^{\circ} \mathrm{C}$ during the past century (Millett and others, 2009). The average increase in minimum daily temperatures has been greater than the average increase in maximum daily temperatures with the largest changes taking place during the winter (Millett and others, 2009). Additionally, the growing season in North Dakota has lengthened by an average of 1.2 days per decade from 1879 to 2008 (Badh and others, 2009). The trends are similar to those taking place in Canada (Zhang and others, 2000) and reflect global average increases in temperature (Intergovernmental Panel on Climate Change, 2013). Across the PPR, precipitation varied by region but on average increased by 9 percent during the twentieth century (Millett and others, 2009). Most of the increased precipitation took place in the southeast part of the region (Ballard and others, 2014) and during the last decade of the century (Garbrecht and Rossel, 2002). However, observed wetting trends are within the range of natural variability and therefore, might not continue (Ballard and others, 2014).

\section{Modeling Wetland Response to Climate Change}

Modeling of prairie wetland hydrology began with a spatial simulation model called WETSIM (WETland SIMulator). WETSIM consisted of two rule-based submodels that simulated hydrologic and vegetative dynamics of a prairie pothole wetland (Poiani and Johnson, 1991, 1993a, 1993b; Poiani and others, 1995, 1996). The early versions of the WETSIM model (WETSIM 1.0-2.0) were set up and tested using data from a single semi-permanent wetland with a comprehensive hydrologic dataset. The effects that a changing climate would have on the prairie pothole wetland were explored by forcing different climate scenarios on the simulated wetland using the WETSIM model (Poiani and Johnson, 1991, 1993a; Poiani and other, 1995). Temperature and precipitation scenarios were based on current general circulation models at the time. The results of these initial climate-forcing experiments indicated that the simulated wetland would become less dynamic under a warming climate as predicted with a doubling of atmospheric carbon dioxide $\left(\mathrm{CO}_{2}\right)$. Overall, water levels in the wetland were lower under scenario conditions as compared to historic conditions. The wetland also spent more time dry and choked by stands of emergent cover under the conditions simulated. The results indicated that climate change could have consequences for wildlife that depend on prairie pothole wetlands because of a decline in habitat quality.

WETSIM 1.0-2.0 only assessed surface processes as related to wetland dynamics and did not include land management as a variable. Thus, WETSIM 3.0-3.1 was developed to include groundwater interactions and integrate land management effects. WETSIM 3.1 and 95 -year climate datasets from 18 weather stations located across the PPR were used to assess the effects of climate change across the PPR (Johnson and others, 2005). The three different climate scenarios that were simulated are as follows: (1) a $3{ }^{\circ} \mathrm{C}$ temperature increase, (2) a $3{ }^{\circ} \mathrm{C}$ temperature increase with a concurrent 20 percent increase in precipitation, and (3) a $3{ }^{\circ} \mathrm{C}$ temperature increase with a 20 percent decrease in precipitation. Model results fluctuated with each treatment. A $3{ }^{\circ} \mathrm{C}$ temperature increase alone caused a shift of favorable water and vegetative cover conditions to the northern and eastern edges of the PPR. When temperature and precipitation were increased, the output was similar to the historical simulations. The increases in precipitation in conjunction with the temperature increase created a counterbalancing effect. A co-occurring increase in temperature and decrease in 
precipitation had the greatest effect; causing favorable habitat conditions to shift to the very southeast corner of the PPR. In general, wetlands located in the drier, western parts of the PPR were determined to be most at risk. Only a substantial increase in precipitation was determined to ameliorate the effects of elevated temperatures (Johnson and others, 2005).

To overcome limitations of the WETSIM model, a new model was developed (Johnson at others, 2010). This new model, WETLANDSCAPE, was able to simulate wetland surface area, vegetation, and groundwater dynamics of multiple wetlands, specifically three temporary, three seasonal, and four semi-permanent wetlands. Within the set, interactions among wetlands could transpire by means of overland flow. Using climate data for the region, Cover Cycle Index (CCI) values were assigned for the complex. The $\mathrm{CCI}$ is a measure of the percentage of time a wetland spends in the hemimarsh stage (equal percentage of open water and emergent vegetation) and the number of cover-cycle stage changes. Prairie wetlands cycle among the following four stages: (1) a dry stage with thick emergent cover, (2) a regenerating stage where reflooding and subsequent germination from a seed bank take place, (3) a degenerating stage where emergent plant growth starts to decline because of high water, and (4) a lake stage where water is at a maximum and emergent vegetation is restricted to the shoreline (van der Valk and Davis, 1978). A complete cycle among the stages is called a wetland's "return time" and potentially affects wetland productivity (Swanson and others, 2003). The CCI has not been rigorously evaluated; however, Johnson and others (2010) indicated that the CCI could be used as a metric of wetland productivity (i.e. higher CCI values represent higher productivity).

The WETLANDSCAPE model was calibrated using 13 years of water-level and groundwater data and 3 years of field observations. Using 100-year datasets from 19 weather stations located across the PPR, temporal and spatial changes in wetland dynamics were detected. To test changes in wetland hydroperiod and CCI values, three future climate scenarios were applied. The scenarios included a $2{ }^{\circ} \mathrm{C}$ temperature increase, a $4{ }^{\circ} \mathrm{C}$ temperature increase, and a $4{ }^{\circ} \mathrm{C}$ temperature increase with a 10 percent increase in precipitation. With each $2{ }^{\circ} \mathrm{C}$ temperature increase, the open-water (that is, ice-free) season extended by about 10 days (Johnson and others, 2010). A $4{ }^{\circ} \mathrm{C}$ temperature increase extended the open-water season by $13-26$ percent. The temperature change had a greater effect on retracting spring thaw than on extending fall freeze, and the more permanent wetlands were affected greatest by a changing climate. Unexpectedly, temporary wetlands were determined to be the most resilient wetland type. In the historic

simulation, the most favorable CCI class covered 47 percent of the PPR and was mainly located in the central PPR (Johnson and others, 2010). This region is known for its high waterfowl production (Batt and others, 1989). As the temperature was increased, the region with the highest CCI values shifted towards the east (fig. 3). With a $4{ }^{\circ} \mathrm{C}$ temperature increase, highest CCI values occurred in the very southeastern and northeastern areas of the PPR. The percentage of the favorable
CCI values decreased to 30.8 and 12.5 percent for 2 and $4{ }^{\circ} \mathrm{C}$ temperature increases, respectively. When a $4^{\circ} \mathrm{C}$ temperature increase was paired with a 10 percent precipitation increase, the results were similar to that of the $2{ }^{\circ} \mathrm{C}$ temperature increase scenario. In general, a 5-7 percent precipitation increase was needed to counteract a $1{ }^{\circ} \mathrm{C}$ temperature increase (Johnson and others, 2010). Water levels and hydroperiod also decreased significantly (fig. 4). A hydroperiod of 100 days historically occurred 22 out of 100 years; however, under a warmer climate this frequency would decline sharply (Johnson and others, 2010). The results of the model indicate that reductions in hydroperiod would likely have detrimental effects on wetland dependent species that require a minimum hydroperiod length for breeding or life cycle completion.

The WETLANDSCAPE model was also used to hindcast simulated wetland variability for the PPR over two 30-year periods (1946-75; 1976-2005). Using weather records for these two periods, wetland conditions were simulated to observe any changes that may have been because of climate change (Werner and others, 2013). Data from 19 weather stations located across the PPR were used to calculate the CCI values for each location for the two periods. Changes in temperature and precipitation caused changes in CCI values for the PPR. The area covered by the least productive CCI class increased from 40-47 percent for the 1946-75 and 1976-2005 periods, respectively (Werner and others, 2013). The least productive CCI class increased primarily in the western part of the PPR. Air temperatures in the western region increased the most over any other part of the PPR. The most productive CCI class did not change in extent but instead shifted eastward. Precipitation in the southeast increased causing wetlands to become stuck in an open water stage and not cycle among cover stages as frequently; therefore, CCI values for this region decreased. Generally, there was a northeasterly shift in productivity within the PPR. The simulated changes in CCI values indicated that climate caused a sufficient enough change for the two time periods to produce significant changes in productivity (Werner and others, 2013).

Results from the WETSIM and WETLANDSCAPE models indicate that climate change may cause an eastward shift in the PPR of the most favorable areas for waterfowl (Johnson and others, 2005, 2010; Werner and others, 2013). However, the eastern part of the PPR has the most highly productive farmland; thus, the wetlands in the eastern part of the PPR have been extensively drained to accommodate crop production (Dahl, 1990, 2014; Tiner, 1984, 2003). Although wetland restoration in the PPR has been occurring since the 1960s (Knutsen and Euliss, 2001), only 1 percent of the wetlands in the eastern region of the PPR have been restored, primarily because of the high cost of obtaining easements on the productive farmlands (Johnson, 2005). However, the results should be interpreted with caution as modeled shifts in favorable wetland habitat may be because of a lack of spatial and temporal variation in the model design. Additionally, the CCI used in the WETLANDSCAPE model has not been evaluated rigorously as a metric for either wetland or 


\section{A. Historic}

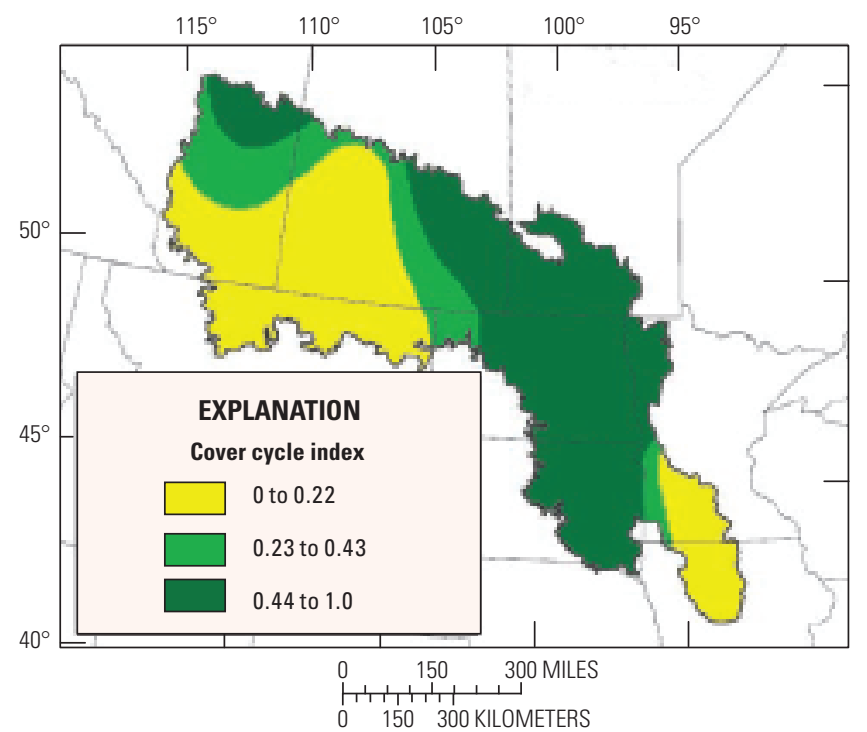

C. Temperature plus 4 degrees Celsius

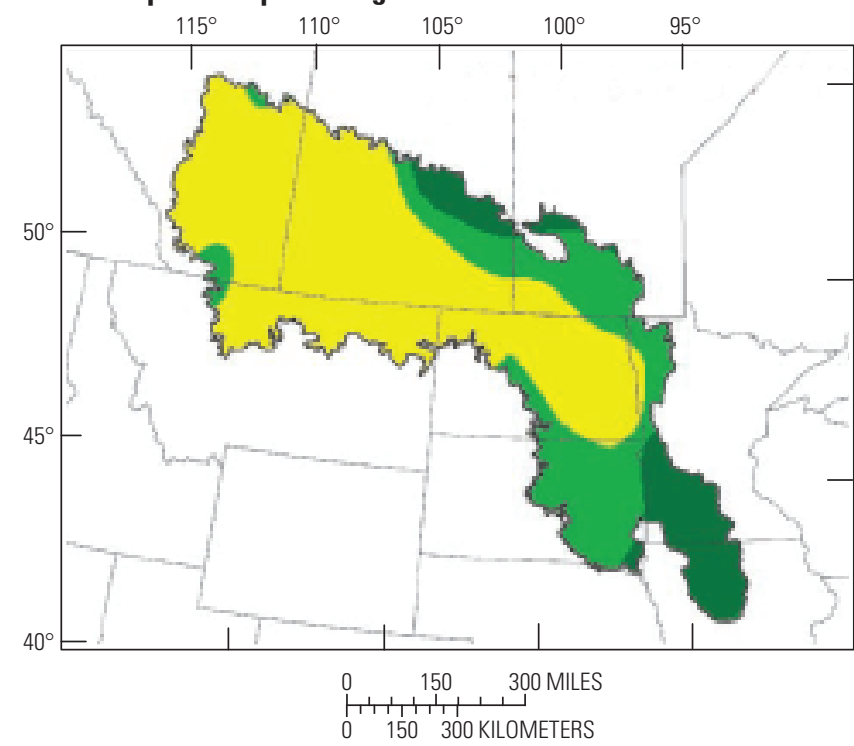

B. Temperature plus 2 degrees Celsius

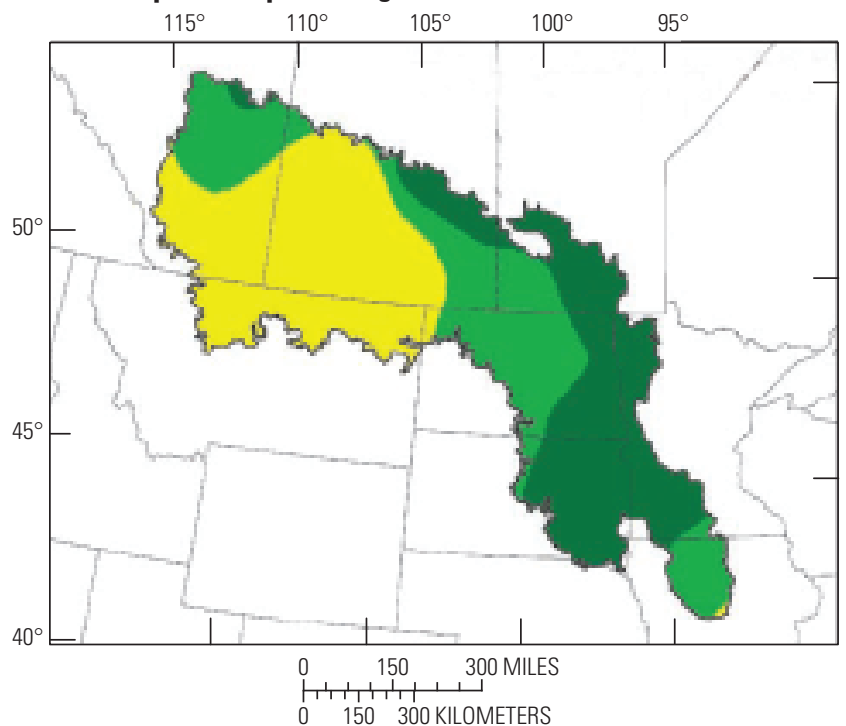

D. Temperature plus 4 degrees Celsius, Precipitation plus 10 percent

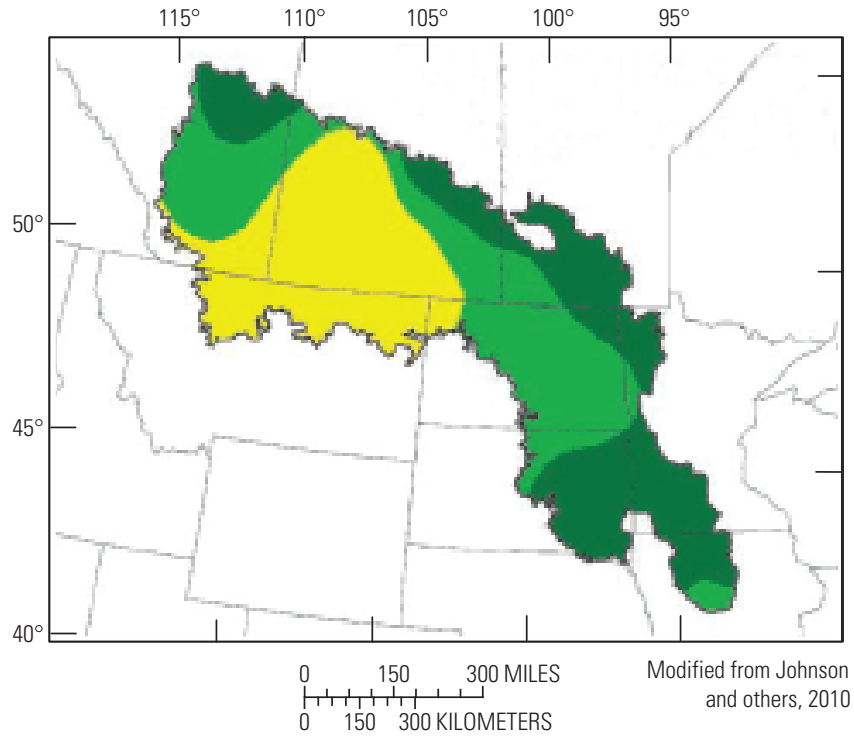

Figure 3. Shifts in the cover cycle index for the Prairie Pothole Region under several climate change scenarios.

waterfowl productivity, and even assumed relations between semi-marsh conditions and productivity have recently been brought into question (Euliss and Smith, 2010).

Separate from the WETSIM and WETLANDSCAPE efforts, a set of models were developed based on analyses of waterfowl breeding and habitat survey data (Larson, 1995). Data consisted of waterfowl and wet basin counts from aerial surveys done in May of each year by the U.S. Fish and Wildlife Service and the Canadian Wildlife Service (Henny and others, 1972). Because of the large area covered by the surveys, these models accounted for geographic differences in wetland morphology. A post-hoc stratification of the survey data into U.S. grassland, Canadian grassland, and Canadian parkland regions was performed and each region was modeled independently. The models for Canadian grassland and parkland regions were created using data from 1968 to 1990 and the U.S. grassland model was created using data from 1973 to 1987 (Larson, 1995). Historical climate datasets that included monthly maximum, minimum, and average temperatures and total precipitation were also obtained (Larson, 1995). Linear regression was then used to explore the relations between the number of wet basins and climate for each of the three regions (Larson, 1995). The models were then tested and run for part of the study area to estimate model accuracy. The models explained 63-65 percent of the variation in number of wet basins for the three regions, indicating that 


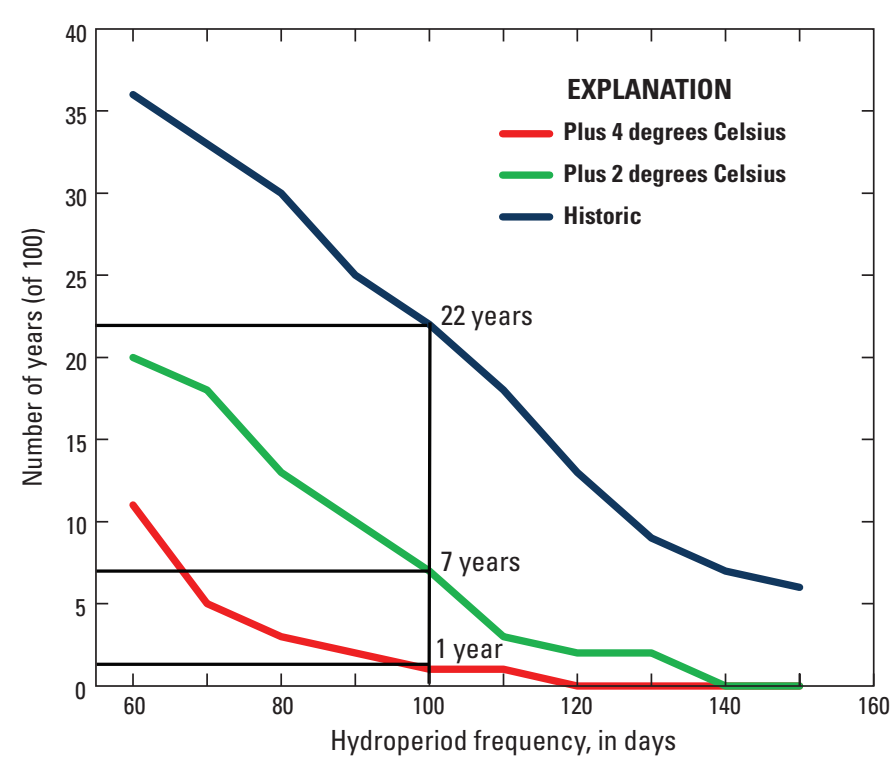

Modified from Johnson and others, 2010

Figure 4. Frequency of hydroperiod calculated for a seasonal prairie pothole wetland. Vertical line shows frequency of a 100day hydroperiod.

climate is the primary driver in wetland dynamics (Larson, 1995). The models accurately simulated the number of wet basins with the use of climate data, and the models held up to tests of random data deletion.

In order to elucidate the effects of climate change on the number of wet basins in the PPR, a set of six climate scenarios was imposed on the models (Larson, 1995). The six scenarios tested were $+3{ }^{\circ} \mathrm{C},+6{ }^{\circ} \mathrm{C},+10$ percent precipitation, $+3{ }^{\circ} \mathrm{C}$ and +10 percent precipitation, -10 percent precipitation, and $+3{ }^{\circ} \mathrm{C}$ and -10 percent precipitation. Effects were not uniform for each of the three regions (table 1). All regions experienced a decline in number of wet basins with an increase in temperature alone; however, the effects were greatest in the Canadian Parkland region. An increase in precipitation of 10 percent resulted in an even increase in percent wet basins across all regions. A 10 percent precipitation increase was able to ameliorate some of the effects of an increase in temperature. A decrease in precipitation had a negative impact on the number of wet basins, with all regions affected similarly.
The largest decrease in number of wet basins was a $3{ }^{\circ} \mathrm{C}$ increase and a 10 percent decrease in precipitation. Again, the Canadian Parkland region was most affected. Through this analysis, Larson (1995) was able to ascertain that PPR wetlands are sensitive to climate change and identified the Canadian Parkland region as being especially vulnerable.

In another attempt to link climate to the number of wet basins and waterfowl numbers, the Palmer Drought Severity Index (PDSI) was used as an indicator of habitat conditions and vulnerability of prairie pothole wetlands to climate change (Sorenson and others, 1998). The PDSI uses climate data to create a water budget that takes supply and demand into account. Monthly precipitation and temperature values are balanced using soil moisture, stored water, runoff, potential evaporation, and previous conditions. Values are normalized so that comparisons can be made among different geographic locations and time frames. The PDSI is a scale from approximately +8.0 to -8.0 , with wetter conditions being reflected by higher values and drier conditions by lower values (Palmer, 1965). May PDSI values were obtained for 22 climate divisions within the U.S. parts of the PPR during 1955-96. The PDSI values were then correlated with the number of wet basins and total duck populations from nine survey strata collected by the U.S. Fish and Wildlife Service (Henny and others, 1972). Results indicated that May PDSI values not only correlated strongly with the number of May ponds but also with breeding duck populations (fig. 5).

A model was then created using a linear regression between May PDSI values and the number of wet basins and total numbers of ducks, and then the model was tested to fit archival PDSI values from 1931 to 1990 (Sorenson and others, 1998). This model was used to simulate the number of wet basins and duck populations under scenarios that included temperature increases of $0,1.5,2.5$, and $4.0^{\circ} \mathrm{C}$; and precipitation changes of $-10,0,+7$, and +15 percent applied uniformly across all months. Changes in temperature and precipitation altered PDSI values, which in turn affected the number of May ponds and the breeding duck population (Sorenson and others, 1998; fig. 6). An increase in temperature of $1.5^{\circ} \mathrm{C}$ alone caused the PDSI value to average -2.61 for April through August, which caused about a 40 percent decrease in the number of May ponds and the breeding duck population. Increases of 2.5 and $4.0^{\circ} \mathrm{C}$ caused extreme

Table 1. Projected percentage of wet basins per year in the Prairie Pothole Region under differing climate change scenarios.

[From Larson (1995); ${ }^{\circ} \mathrm{C}$, degrees Celsius]

\begin{tabular}{|c|c|c|c|c|c|c|c|}
\hline \multirow[b]{2}{*}{ Region } & \multicolumn{7}{|c|}{ Mean percentage of wet basins per year (percentage change in parentheses) } \\
\hline & Historical & $+3^{\circ} \mathrm{C}$ & $+6^{\circ} \mathrm{C}$ & $\begin{array}{c}\text { +10 percent } \\
\text { precipitation }\end{array}$ & $\begin{array}{c}+3^{\circ} \mathrm{C} \text { and } \\
+10 \text { percent } \\
\text { precipitation }\end{array}$ & $\begin{array}{l}\text {-10 percent } \\
\text { precipitation }\end{array}$ & $\begin{array}{c}+3^{\circ} \mathrm{C} \text { and } \\
-10 \text { percent } \\
\text { precipitation }\end{array}$ \\
\hline Canadian parkland & 51.5 & $22.4(-56)$ & $4.5(-91)$ & $57.2(+13)$ & $31.2(-38)$ & $36.3(-28)$ & $13.4(-74)$ \\
\hline Canadian grassland & 49.2 & $42.0(-15)$ & $35.1(-29)$ & $55.0(+12)$ & $50.0(+2)$ & $38.9(-21)$ & $34.1(-31)$ \\
\hline
\end{tabular}




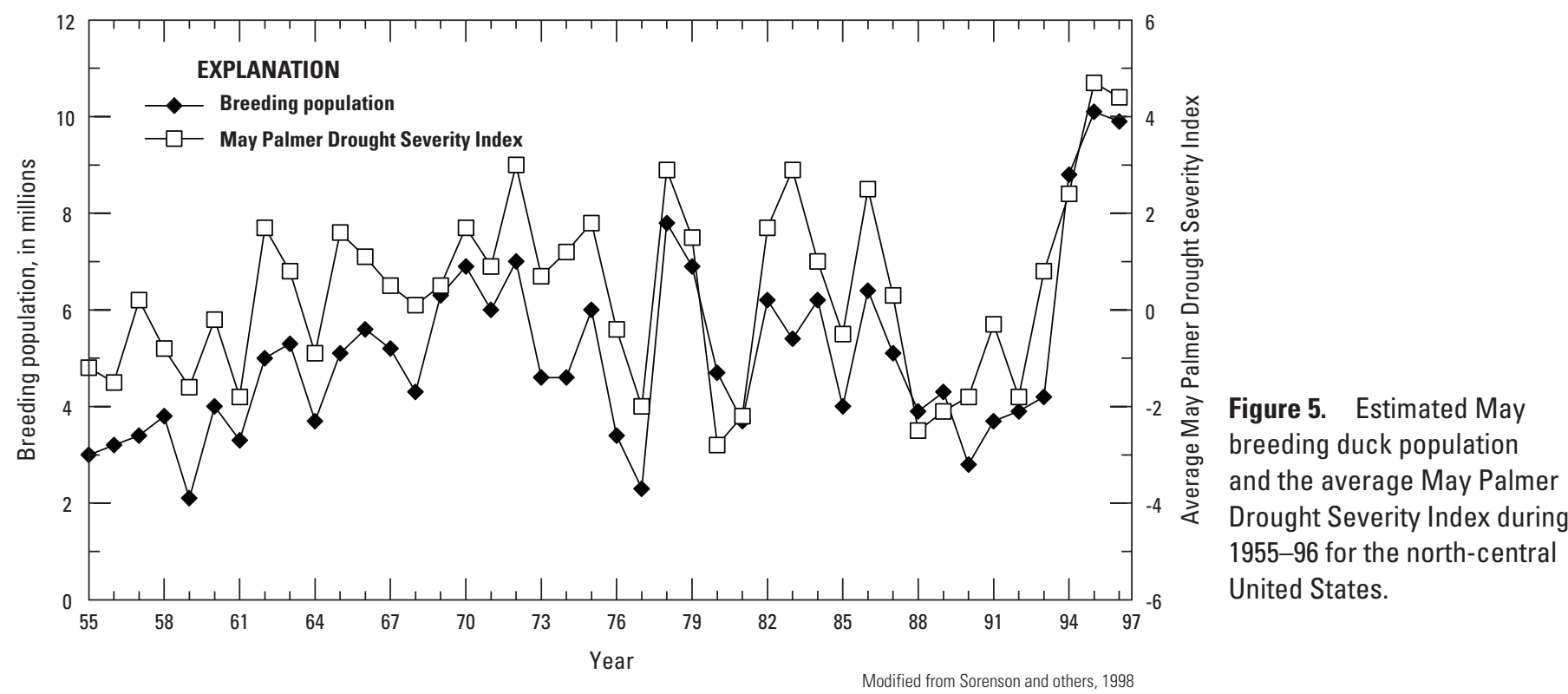

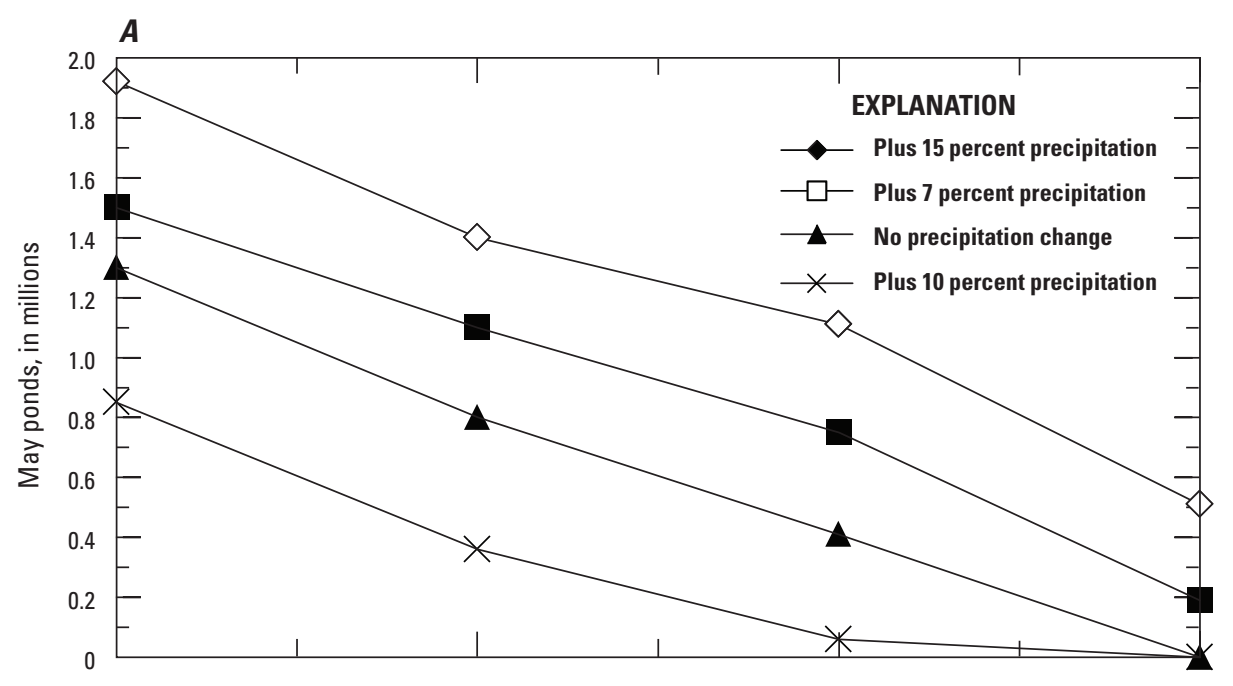

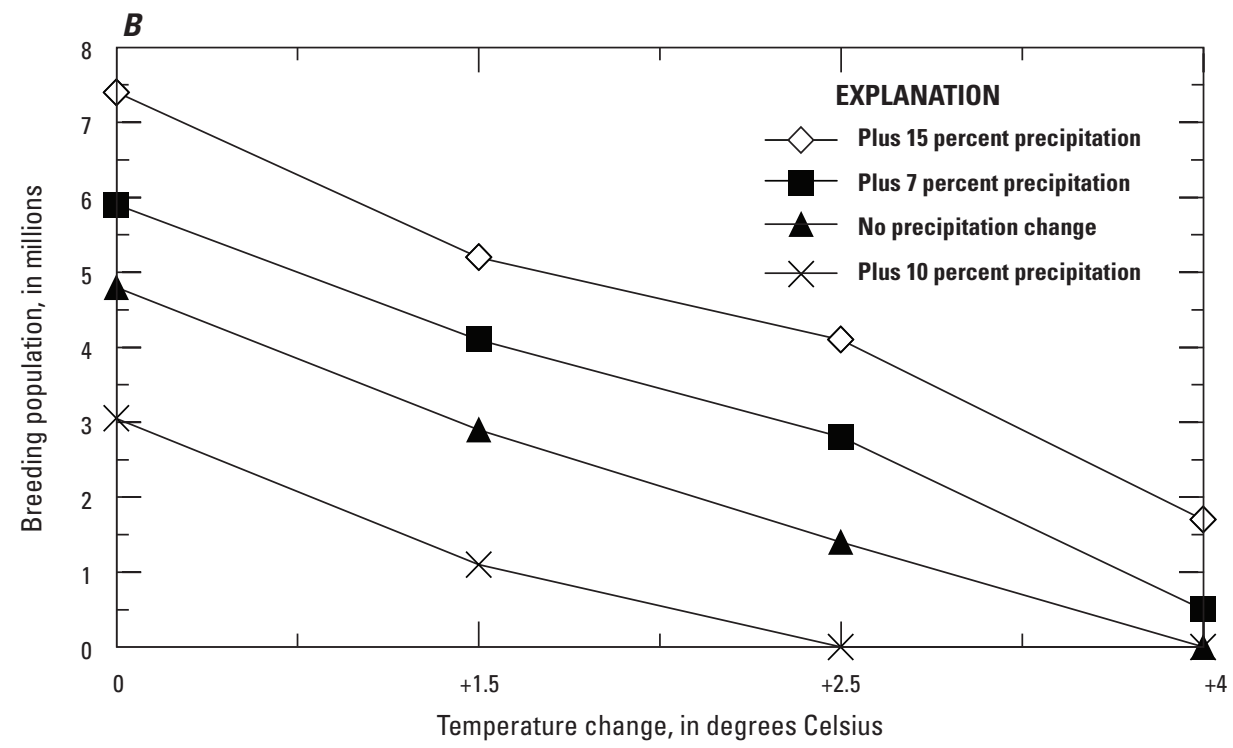

Figure 6. May ponds and waterfowl populations under different scenarios of temperature and precipitation. $A$, Simulated number of wet basins and $B$, simulated breeding waterfowl population. Dashed line represents the historical average during 1955-96. 
drought conditions with PDSI values less than -4 and losses of wet basins and duck populations by 70 percent or more. Increases in precipitation were able to compensate for some of the effects of higher temperatures but generally were not enough to negate the effects. Of the 12 scenarios that had increases in temperature, only 1 did not result in lower PDSI values; a 15 percent increase in precipitation fully compensated for the effects of a $1.5^{\circ} \mathrm{C}$ temperature increase. Results from the simulations indicate that large increases in precipitation are needed in order to lessen the effects caused by increased temperature (Sorenson and others, 1998).

Sorenson and others (1998) also tested two general circulation models. The first general circulation model was developed by the Geophysical Fluid Dynamics Laboratory (GFDL Q-flux model; Manabe and Wetherald, 1987) and involved an immediate doubling of atmospheric $\mathrm{CO}_{2}$. The second model was developed by the United Kingdom Hadley Center (UKHC; Murphy and Mitchell, 1995) and involved a gradual increase of atmospheric $\mathrm{CO}_{2}$ by 1 percent each year. Simulations using the GFDL Q-flux and UKHC models revealed increased drought conditions and decreased numbers of May ponds and duck populations under a changing climate (table 2; Sorenson and others, 1998). The GFDL Q-flux model that doubled atmospheric $\mathrm{CO}_{2}$ levels caused average May PDSI values to drop to -3.40 ; the historical PDSI average was 0.37 . The lower PDSI values were associated with a 54 percent drop in May pond numbers and a 58 percent reduction in the breeding duck population. The UKHC model revealed that, by the 2020s and 2050s, May PDSI averages would drop to -1.41 and -2.59 , respectively. May pond numbers would concurrently decrease by 23 and 38 percent for the 2020s and 2050s, respectively. This decrease in May ponds would cause duck populations to decrease 26 percent by the 2020 s and 46 percent by the 2050 s.

Table 2. May Palmer Drought Severity Index, May ponds, and May duck populations for historical conditions based on Geophysical Fluid Dynamics Laboratory Q-flux and United Kingdom Hadley Center general circulation models.

[PDSI, Palmer Drought Severity Index; GFDL, Geophysical Fluid Dynamics Laboratory; UKHC, United Kingdom Hadley Center; $\mathrm{CO}_{2}$, carbon dioxide]

\begin{tabular}{lccc}
\hline \multicolumn{1}{c}{ Scenario } & $\begin{array}{c}\text { May } \\
\text { PDSI }\end{array}$ & $\begin{array}{c}\text { May } \\
\text { pond } \\
\text { numbers } \\
\text { (millions) }\end{array}$ & $\begin{array}{c}\text { May } \\
\text { breeding duck } \\
\text { population } \\
\text { (millions) }\end{array}$ \\
\hline Historical (1955-96) & 0.37 & 1.3 & 5.0 \\
GFDL model (2 $\mathrm{CO}_{2}$ ) & -3.40 & 0.6 & 2.1 \\
UKHC model 2020s & -1.41 & 1.0 & 3.7 \\
UKHC model 2050s & -2.59 & 0.8 & 2.7 \\
\hline
\end{tabular}

A similar approach was used to detect the effect of PDSI on wetland surface area in the PPR (Ouyang and others, 2014). The PDSI was correlated with wetland surface area obtained from 1986-2011 Landsat imagery, and a linear model able to predict wetland surface area under future climate scenarios was created (Ouyang and others, 2014). Using this model, wetland surface area fluctuated with changes in PDSI and was consistently lower for simulations based on Intergovernmental Panel on Climate Change (IPCC) fourth assessment report 22 -model ensemble climate. The average wetland surface area for the climate change scenario was 41.9 percent of the historical average. The PDSI values from previous years were also correlated with current-year wetland-surface-area values, with values from 1 year earlier having the greatest correlation (Ouyang and others, 2014). In conjunction with the results of Sorenson and others (1998), the PDSI was a good proxy measure for wetland surface area with changes in PDSI values because of climate change resulting in substantial effects on wetland dynamics (Ouyang and others, 2014).

Niemuth and others (2010) indicated that spatial and temporal variations in wetland dynamics are highly variable and complicate efforts to simulate changes in wetland dynamics caused by climate change. In an effort to detect spatial and temporal trends in prairie pothole wetlands caused by climate, wetland class, and geographic position; spatial and temporal patterns of roughly 40,000 wetlands within the PPR of North Dakota, South Dakota, and Montana were simulated (Niemuth and others, 2010). Each wetland within 263-380 sample blocks was assessed with aerial photography taken in May of each year between 1988 and 2007. The period sampled included drought and deluge (Niemuth and others, 2010). Percent wet area and percent wet basins fluctuated with the changes in climate. All sample wetland photography was digitized and wetlands were assigned a class category of temporary, seasonal, semipermanent, or lake. Then, a baseline was created using data from the National Wetlands Inventory (Wilen and Bates, 1995), and the baseline was used to compare the new data to estimate changes in percent wet area and percent wet basins. The baseline data were generated using historic wetland conditions during periods when wetland basins were full but not overflowing. Each wetland class was analyzed separately to determine if interannual wetland dynamics differed by wetland class.

Variability in percent wet area and percent wet basins was related to the permanence of the wetland, with temporary wetlands being the most variable and lakes being the least. Temporary wetlands consistently had the lowest percent wet area and percent wet basins, whereas lakes had the highest values for both. Correlations between current wetland conditions and previous conditions were highest for the lake regime and lowest for the temporary regime (Niemuth and others, 2010). Effects of previous percent wet area values on current values were also analyzed (Niemuth and others, 2010). Conditions from 1 year earlier had the highest correlation to present conditions and steadily declined each year thereafter. Also, the 
percent wet area varied spatially for each regime and did not form a discrete east-west gradient of wetness.

Niemuth and others, (2010) noted several analysis limitations. Intra-seasonal effects could not be detected because wetlands were only sampled in May of each year. Current conditions and changes in land use surrounding the wetlands were not taken into consideration. Also, the results from the study were dependent on the baseline data used. Models developed within a limited spatial context and that precluded the use of the range of wetland classes may not reveal the complex variance among wetlands in the PPR. Therefore, further monitoring strategies and analyses of future wetland dynamics need to include greater spatial distribution and consider each wetland class separately (Niemuth and others, 2010). Also, factors such as intensified land use and wetland drainage may overshadow direct effects of climate change and need to be considered when making conservation decisions (Niemuth and others, 2014).

Climate change will differ spatially and temporally. Thus, model comparisons are needed that are not only conducted at large spatial scales but also consider seasonal changes. In such an analysis, Ballard and others (2014) explored climate model projections from phase 5 of the Coupled Model Intercomparison Project (CMIP5) of the IPCC Fifth Assessment in relation to PPR wetland hydrology. Model simulations revealed increases in precipitation across the PPR in all seasons except summer. However, the water-input gains were largely negated by increased evapotranspiration that accompanied increases in temperatures and evaporative demand. Seasonal surface drying in the summer corresponds to the combined effects of warming and precipitation changes (Ballard and others, 2014). However, uncertainties resulting from imperfect knowledge of future climates again necessitate caution when considering model results (Zhang and others, 2011).

\section{Monitoring Wetland Response to Climate Change}

Data compiled from wetland monitoring programs within the PPR are crucial to answering questions regarding the effects of climate change on wetland dynamics in the region. In a review of the monitoring strategies, current monitoring networks were determined to be insufficient to examine effects of climate and land use over a broad spatial scale (Conly and van der Kamp, 2001). For monitoring networks to be effective, two strategies, intensive and extensive, need to be implemented together (Conly and van der Kamp, 2001). The first strategy requires intensive monitoring of an array of hydrologic data at a relatively small number of sites. There are six such wetland-monitoring sites in Saskatchewan, one in North Dakota, and one in South Dakota. Conly and van der Kamp (2001) indicated that additions be made to the network to include areas that are highly sensitive to climate change. In addition to adding more sites, monitoring at these sites should include perspectives from several disciplines in a way that will increase our understanding of the complex interactions among wetlands within the PPR (Covich and others, 1997). Data such as streamflow, groundwater, and water quality should be included in intensive monitoring efforts to shed light on hydrologic and ecological interactions (Conly and van der Kamp, 2001).

Extensive monitoring consists of focusing on fewer hydrologic parameters and reducing sampling frequency but covering more wetlands over a broader geographic area. Climatic conditions account for a large percentage of the variation in water levels and hydroperiods of prairie pothole wetlands. However, land use surrounding wetland basins can have large impacts as well. Therefore, land-use data should be included in monitoring programs (Conly and van der Kamp, 2001; Covich and others, 1997). Multiple monitoring sites of similar catchment characteristics but with different surrounding land uses would meet this need (Covich and others, 1997). The data collected at such sites would be crucial to detect spatial differences in natural variation and variation caused by climate change and land use.

\section{Upland Management Effects on Prairie Pothole Wetland Hydrology}

A wetland's water budget is a balance among precipitation, runoff, infiltration, and evapotranspiration (Shjeflo, 1968). Changes in climate can cause considerable effects on the amount of precipitation prairie pothole wetlands receive and the rate at which that water is lost through evapotranspiration. The water budget of a wetland is also altered through different upland management practices that affect runoff, infiltration, and evapotranspiration. Interception of snowfall and rainfall can also be altered through manipulations of vegetative cover. Wetlands in the PPR are located within a matrix of different land uses (Kantrud and others, 1989); therefore, an understanding of land-use impacts will be essential for making future management decisions under a changing climate. Farming practices can have profound effects on wetland conditions (Turner and others, 1987) but are beyond the scope of this study. Instead, the focus is limited to the effects of management practices used on grasslands within the PPR.

\section{Grassland Grazing}

Grazing by livestock can cause changes in the hydrology of a watershed through the removal of plant cover and the physical action of animal hooves on vegetation and soils; however, these effects will differ across regions (Blackburn, 1983). Uncontrolled grazing can have a negative effect on a watershed but can be managed with control of the timing, frequency, and intensity of grazing (Holecheck, 1981). The literature on the impacts of grazing on hydrology is 
scattered with little information on its effects on prairie pothole wetlands. Therefore, our review also includes areas in proximity to the PPR with a focus on grazing impacts to evapotranspiration, infiltration, and runoff.

For prairie regions, evapotranspiration provides the largest deficit to the water budget (Frank and Inouye, 1994). An assessment of impacts of grazing on evapotranspiration rates for a grazed and ungrazed tallgrass prairie site indicated that evapotranspiration was reduced for the grazed site by an average of 28 percent and as much as 40 percent near the end and just after the grazing season (Bremer and others, 2001). This difference was believed to be caused by changes in the vegetative canopy; leaf area index was 78 percent lower for the grazed site. However, after cattle were removed, evapotranspiration rates quickly increased and for a time were higher than the ungrazed site. The temporarily high evapotranspiration rates were the result of new leaf growth and delayed senescence. However, cumulative evapotranspiration was reduced by 6.1 percent on the grazed site. In addition to an overall reduction in evapotranspiration, grazing helped to conserve soil water in the upper 0.3 meter $(\mathrm{m})$ of the soil profile.

A review of the literature on the effects of grazing on infiltration rates was completed by Gifford and Hawkins (1978) in an effort to detect an overall pattern across several regions. However, most of the studies were located in the western United States and the Great Plains. When infiltration rates of grazed pastures were plotted and compared to rates of ungrazed pastures, grazing impacts on infiltration rates were revealed. Although there was no significant difference between light and moderate grazing intensities, heavy grazing significantly reduced infiltration. Lower infiltration rates indicate that more water will be available as runoff to wetlands. However, conclusions were limited because of the lack of information on time-related effects of grazing, the use of data that were generally collected for other purposes and then reconfigured by range hydrologists, and the limitations of the instruments used.
Effects of grazing on vegetation and runoff were studied during 1962-67 within three range pastures. The pastures had been grazed since 1942 with the following grazing intensities: heavy, moderate, and light. In 1962, study sites consisting of four 2-acre plots within each of the three pastures were selected and H-flumes and FW-1 water-level recorders were installed on the downslope of each plot to record runoff. Rain gages were also installed on each watershed to record variations in precipitation. During 1963-67, hydrologic data were collected from May 14 through October 31, and vegetative data were collected in late July. Differences in runoff and vegetation were detected among the three grazing treatments (Hanson and others, 1970). Runoff was greatest for the heavy grazing treatment and lowest for the light grazing treatment with no detectable patterns in precipitation across the treatment sites (table 3 ).

Runoff regimes of the three watersheds were also altered by grazing. During the study period, there were 22,18 , and 13 runoff events for the heavy, moderate, and light treatments, respectively. Smaller rainfall events produced runoff in the heavily grazed plots, whereas heavier rainfall events were needed to produce runoff in the lightly grazed plots. The total weight of vegetation remaining after grazing for the three treatments was 1752,2092 , and 3700 pounds per acre for the heavy, moderate, and light treatments, respectively. Also, the species composition was different for each of the treatment watersheds. The heavily grazed watershed consisted of sedges and short grasses, the moderately grazed watershed mostly consisted of short grasses with some midgrasses, and the lightly grazed watershed primarily consisted of western wheatgrass. This study only focused on the effects of cattle grazing during the growing season and not runoff from winter precipitation.

The effect of range condition on winter runoff and soil water storage was also studied (Hanson and Lewis, 1978). Desired range conditions were created using differing grazing intensities. During 1942-63, three pastures of good range

Table 3. Precipitation and runoff for differentially grazed watersheds.

[From Hanson and others (1970)]

\begin{tabular}{ccccccccc}
\hline \multirow{2}{*}{ Year } & \multicolumn{2}{c}{ Heavy grazing } & & \multicolumn{2}{c}{ Moderate grazing } & & \multicolumn{2}{c}{ Light grazing } \\
\cline { 2 - 3 } & $\begin{array}{c}\text { Precipitation } \\
\text { (inches) }\end{array}$ & $\begin{array}{c}\text { Runoff } \\
\text { (inches) }\end{array}$ & & $\begin{array}{c}\text { Precipitation } \\
\text { (inches) }\end{array}$ & $\begin{array}{c}\text { Runoff } \\
\text { (inches) }\end{array}$ & & $\begin{array}{c}\text { Precipitation } \\
\text { (inches) }\end{array}$ & $\begin{array}{c}\text { Runoff } \\
\text { (inches) }\end{array}$ \\
\hline 1963 & 12.14 & 1.79 & & 12.02 & 1.57 & & 12.61 & 1.39 \\
1964 & 8.59 & 0.66 & & 8.58 & 0.28 & & 7.74 & 0.05 \\
1965 & 10.81 & 0.13 & & 11.05 & 0.14 & & 10.91 & 0.12 \\
1966 & 9.40 & 0.16 & & 9.18 & 0.02 & & 9.45 & 0.00 \\
1967 & 11.00 & 1.21 & & 11.16 & 0.79 & & 10.90 & 0.54 \\
Mean & 10.39 & 0.79 & & 10.40 & 0.56 & & 10.32 & 0.42 \\
\hline
\end{tabular}


condition were grazed for 7 months each year under heavy, moderate, and light grazing intensities to produce range conditions of poor+, good-, and good+. Conditions improved to fair-, good, and excellent- during the duration of the study. Hereafter the pastures will be referred to as being of low, medium, and high range conditions. Within each of the three pastures, four plots were diked off. Runoff was measured using H-flumes and FW-1 water-level recorders, soil water was measured with a neutron probe at $30.5 \mathrm{~cm}$ intervals at $122 \mathrm{~cm}$ depth, and precipitation was recorded at each site with four rain gages.

Average winter runoff values were not significantly different among the three range condition treatments (Hanson and Lewis, 1978). In general, the low condition range had higher fall soil moisture, whereas the high-condition range had lower fall soil moisture. The soil moisture differences can be explained by increased transpiration of the highcondition range because of the presence of more vegetation. Differences in spring soil moisture were less distinct, but the low-condition range typically had lower soil moisture than the medium- and high-condition ranges. Winter soil moisture was directly proportional to range condition, with the lowcondition range having less soil water than the high-condition range. Even though winter runoff values were similar for each range, the amount of winter precipitation stored in the soil was greatest for the high-condition range and lowest for the lowcondition range. The low-condition range not retaining snow as well as the high-condition range can explain differences in precipitation storage. The low-condition range had less standing vegetation and mulch because of excessive grazing; therefore, wind transported snow off the low-condition range. Conversely, the high-condition range had more standing vegetation and mulch. The vegetation and mulch held the falling snow and also trapped the snow transported by the wind. These results indicate that snow is an important source of soil moisture for the Great Plains.

During 1988-91, treatments of short duration and continuous grazing systems were applied on plots to assess the impacts of grazing on runoff and sediment yield (Naeth and Chanasyk, 1996). Grazing intensities of heavy and very heavy were compared against an ungrazed control. Snowmelt accounted for most of the annual runoff, and snowmelt runoff decreased with increased grazing intensity because of less snow entrapment on the grazed pastures. Sediment levels were low for snowmelt runoff and no trend among grazing intensities was detected. Rainfall runoff and sedimentation yield increased with increased grazing intensity.

The results presented in Naeth and Chanasyk (1996) were compiled using small treatment plots; therefore, Chanasyk and others (2003) validated the study by using watershed-scale treatment plots for 1998-2000. The Soil Water Assessment Tool (SWAT) was calibrated for the region in order to predict surface runoff (Chanasyk and others, 2003). Three similar watersheds were chosen and one of three treatments (ungrazed, heavily grazed, and very heavily grazed) was applied to each watershed. Each watershed had only one outlet where runoff could be measured. Climate and vegetative data were also collected at each study site. Surface runoff for all of the treatment sites was very low. Runoff events were sporadic and generally only lasted a few hours. The heavily and very heavily grazed watersheds consistently had higher runoff volumes than the ungrazed watershed; however, differences between heavily and very heavily grazed watersheds were not as clear. In fact, the heavily grazed watershed averaged more runoff during the study period than the very heavily grazed watershed. Vegetative cover decreased with increased grazing intensity; therefore, the grazing intensity did not help explain the observed differences. The difference in slope between the heavily grazed watersheds (average slope of 21 percent) and the very heavily grazed watersheds (average slope of 18 percent) was the only factor that might explain the unexpected results. Similar patterns were seen for snowmelt runoff. Snowmelt runoff only lasted for 2 days on the ungrazed watershed; however, snowmelt runoff lasted for 12 days on the treatment watersheds. The difference in snowmelt runoff days was unanticipated because expectations would be that the ungrazed watershed would have more snow because of more vegetative cover. However, the infiltration rate for this watershed would also be expected to be much greater and may help to explain results. Attempts at simulating runoff values for the watersheds were unsuccessful using the SWAT model. Values were consistently under predicted and may have been a result of the low levels of runoff during the study period and (or) the statistical criteria used (Chanasyk and others, 2003).

In another use of the WETSIM 3.2 model, water runoff, infiltration, and upland evapotranspiration rates were simulated under different land-use scenarios. The land-use scenarios were unmanaged native grass, unmanaged smooth brome grass, moderately heavy grazed native grass, spring burned grass, row crop, small grain, and alfalfa hay (Voldseth and others, 2007). The model was calibrated using data from 1993 to 2001 and was tested against 3 years of data collected after 2001. After calibration and testing, a 41-year simulation was run for the seven land-use scenarios using climate data from 1961 to 2001 (Voldseth and others, 2007). Land use was predicted to have an effect on water levels of wetland SP4 (Voldseth and others, 2007). Water levels were highest under the grazed simulation with a mean water level of $0.85 \mathrm{~m}$, and the unmanaged grassland simulation had a mean water level of $0.67 \mathrm{~m}$. The grazed grassland simulation predicted that wetland SP4 would be dry 22 percent of the simulation period, whereas the unmanaged native grassland would be dry 46.3 percent of the period. By using WETSIM 3.2, Voldseth and others (2007) concluded that grazing could have a significant effect on prairie pothole wetland water levels because of changes in runoff, infiltration, and upland evapotranspiration caused by grazing cattle.

The potential of using management and farming practices as climate change mitigation strategies for prairie pothole wetlands was also tested using the WETSIM 3.2 model (Voldseth and others, 2009). Wetland dynamics in unmanaged 
native grassland, unmanaged non-native grassland, grazed grassland, row crop, and small grain crop under historical climate conditions and several climate change conditions were modeled. The climate change simulations include $+2{ }^{\circ} \mathrm{C}$, $+4{ }^{\circ} \mathrm{C},+2{ }^{\circ} \mathrm{C}$ and +10 percent precipitation, $+2{ }^{\circ} \mathrm{C}$ and -10 percent precipitation, $+4{ }^{\circ} \mathrm{C}$ and +10 percent precipitation, and $+4{ }^{\circ} \mathrm{C}$ and -10 percent precipitation. Model runs revealed that changes in land use did have effects on wetland hydrology that, under certain scenarios, could ameliorate effects of climate change (table 4). Under all climate scenarios, wetlands with unmanaged native and non-native grass catchments had lower than historical water levels. The grazed grass treatment had the largest potential for mitigating climate change effects on prairie pothole wetlands (Voldseth and others, 2009). However, the simulation was based on small amounts of empirical data and further studies are needed to confirm the results.

\section{Grassland Burning}

Several studies have looked at the effects of fire on runoff and water yield outputs (for example, Robichaud and Waldrop, 1994; Helvey, 1980; DeBano, 2000; BenavidesSolorio and MacDonald, 2001). However, most research has focused on forested watersheds. In forested watersheds, fire generally increases water yield by altering patterns of evapotranspiration, infiltration, and runoff. Burning within a watershed reduces the amount of vegetative and mulch cover; thus, the amount of precipitation intercepted by the soil surface will increase. This water can then go back to the atmosphere through evapotranspiration, infiltrate into the soil, or runoff into a stream or wetland (DeBano and others, 1998). Evapotranspiration decreases immediately after a fire, likely because of temporary elimination of transpiring vegetation (Neary, 1995). Small decreases in evapotranspiration even can create relatively large increases in runoff (Ffolliott and Thorud, 1977). Infiltration rates after a fire often decrease as well because of the removal of organic material causing soil structure to collapse, raindrop impacts causing soil surfaces to compact, and (or) residue from ash causing soil pores to clog.
Therefore, runoff will increase because of the decreases in infiltration and evapotranspiration (DeBano and others, 1998). Literature pertaining to the hydrologic effects of fire within the PPR is scarce. However, some generalizations can be made using data from other grassland watersheds.

The effects of prescribed burning on the surface hydrology of a tallgrass prairie were assessed by Koelliker and Duell (1990). The researchers established four plots; two plots were burned in May of 1989 and the other two plots were left unburned. Rainfall simulations were conducted throughout the following growing season on all of the plots. Initial infiltration rates were 19 millimeters per hour $(\mathrm{mm} / \mathrm{hr})$ lower for the burned plots; however, over longer timespans, differences decreased. Infiltration rates on one of the burned plots rebounded to the rate of the unburned plot after 40 days; infiltration on the other burned plot remained significantly lower. Runoff from the burned plots was initially 70 percent greater than the unburned plots. However, after 40 days runoff volumes were about equal between treatments. Runoff velocities were 10 percent greater for the burned plots but did not significantly increase erosion for slopes between 5 and 10 percent. Prescribed burning caused an increase in runoff volume (Koelliker and Duell, 1990) even though evapotranspiration rates increased after a burn for the same area (Bremer and Ham, 1999).

The hydrologic effects of prescribed burning were assessed for oak, juniper, bunchgrass, and shortgrass dominated watersheds (Hester and others, 1997). Results from bunchgrass and shortgrass sites will be discussed. Each site was burned in July 1991. Following the burn, a drip-type rain simulator was used to determine infiltration rates and sediment yields from each of the burned and unburned sites. Rainfall events were simulated for 50 minutes at a rate of $203 \mathrm{~mm} /$ hour and runoff was collected and measured every 5 minutes. Vegetative and litter cover were also determined for each site, and soil was sampled and tested for texture, organic carbon content, and aggregate stability. Vegetation type had a strong impact on range hydrology (Hester and others, 1997). The shortgrass site had the lowest infiltration rate followed by the bunchgrass site. For both grassland sites, infiltration rates decreased over time for burned and

Table 4. Mean wetland water levels for each land-use type under several climate change scenarios.

[From Voldseth and others (2009); ${ }^{\circ} \mathrm{C}$, degrees Celsius; bolded values are equal to or greater than the historical value]

\begin{tabular}{|c|c|c|c|c|c|c|c|}
\hline \multirow[b]{2}{*}{ Land use } & \multicolumn{7}{|c|}{ Mean water level (meters) } \\
\hline & Historical & $+2^{\circ} \mathrm{C}$ & $+4^{\circ} \mathrm{C}$ & $\begin{array}{l}+2{ }^{\circ} \mathrm{C} \text { and } \\
+10 \text { percent } \\
\text { precipitation }\end{array}$ & $\begin{array}{c}+2{ }^{\circ} \mathrm{C} \text { and } \\
-10 \text { percent } \\
\text { precipitation }\end{array}$ & $\begin{array}{l}+4^{\circ} \mathrm{C} \text { and } \\
+10 \text { percent } \\
\text { precipitation }\end{array}$ & $\begin{array}{l}+4{ }^{\circ} \mathrm{C} \text { and } \\
-10 \text { percent } \\
\text { precipitation }\end{array}$ \\
\hline Native grass & 0.67 & 0.54 & 0.43 & 0.62 & 0.46 & 0.49 & 0.37 \\
\hline Brome grass & 0.66 & 0.53 & 0.41 & 0.61 & 0.45 & 0.48 & 0.36 \\
\hline Grazed grass & 0.85 & 0.73 & 0.58 & 0.83 & 0.62 & 0.69 & 0.49 \\
\hline Row crop & 0.80 & 0.66 & 0.52 & 0.76 & 0.56 & 0.62 & 0.44 \\
\hline Small grain & 0.77 & 0.64 & 0.51 & 0.74 & 0.54 & 0.59 & 0.43 \\
\hline
\end{tabular}




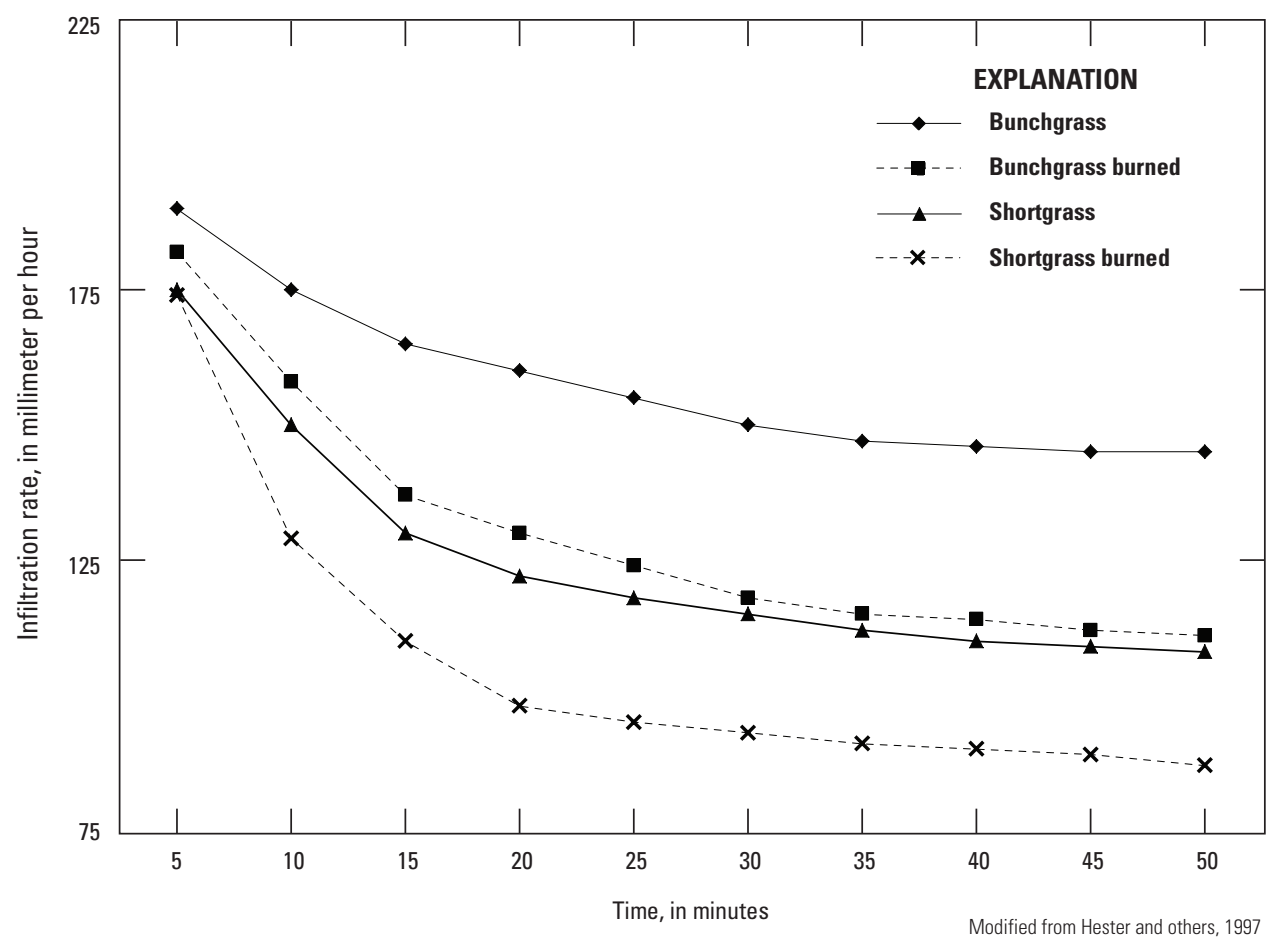

Figure 7. Infiltration rates from 50-minute simulated rainfall event for burned and unburned sites.

unburned treatments. Burning affected the hydrology on all the vegetation types (fig. 7). On average, infiltration declined by about 25 and 28 percent for bunchgrass and shortgrass, respectively. Sediment yields for both grassland sites increases significantly; however, changes in soil structure were insignificant. The amount of sediment yield was strongly correlated with total organic cover, which had been completely removed in both grassland sites after burning. However, burning on slopes less than 20 percent for this region would not likely create serious erosion or water-quality problems and could be left to recover naturally (Wright and others, 1976).

As described previously, Voldseth and others (2007) used the WETSIM model to predict changes in wetland water levels caused by several land uses and management strategies. A spring burn simulation yielded similar results as grazing simulations. A spring burn simulation produced about a 20 -percent increase in average annual water level, compared to the unmanaged native grass simulation. However, empirical data and further research on the effects of prescribed burning on the hydrology of PPR grasslands and wetlands are needed to validate these findings (Voldseth and others, 2009).

\section{Snow Management}

Snowmelt is the most crucial water input to prairie pothole wetland water budgets, even though it only makes up roughly one-third of the annual water supply for much of the PPR (Shjeflo, 1968; Gray and Landine, 1988; Kantrud and others, 1989; LaBaugh and others, 1998). Snowmelt may account for as much as $80-85$ percent of the total surface runoff for prairie habitats because of soils being frozen at the time of snowmelt (Gray and others, 1970). This snowmelt runoff provides an initial surplus of water that is available for waterfowl early in the season. The input from snowmelt alone can generally last until early July. However, additional rainfall is needed to sustain wetland water levels for the season (Shjeflo, 1968). For many northern and high altitude regions, water from snowmelt is essential for streamflow, soil moisture, groundwater recharge, and human use (Pomeroy and Gray, 1995). Because of the importance of snowmelt to prairie pothole water levels, many techniques have been used to manage snow in ways that provide increased water output from snowmelt.

After snow has been intercepted by the landscape it is readily moved by wind, causing its distribution and structure to change. Snow is transported until it forms drifts because of vegetation, topography, or manmade barriers. As snow forms drifts, the snow not only becomes deeper, but also denser as the snow is packed together and individual flakes lose their crystalline structure. This process is known as snow metamorphism and is caused not only by the physical action of snow packing but also by temperature and water vapor gradients (Pomeroy and Gray, 1995). Drifted snow has been as much as six times denser after a period of less than 24 hours for a site on the Canadian Prairies (Gray and others, 1970). As a snowdrift becomes larger and denser, snow water equivalent increases (Pomeroy and Gray, 1995). Snow water equivalent is the measure of how much water is stored within a given volume of snow and can be calculated from snowpack depth 
and density. Snow water equivalent can also be affected by ambient temperature, heat exchange within the snow pack from condensation, radiation and conduction, and percolation of water through the pack (Gray and others, 1970).

Snow accumulation can be managed with the use of manmade or vegetative barriers. Manmade snow fences primarily consist of three types; horizontal wood slat, vertical wood slat, and synthetic fences. The horizontal-slat fence is typically used for permanent fences to control snow drifting across highways (Tabler, 1991), whereas the vertical-slat and synthetic fences work better for temporary snow fence designs. Synthetic fencing most commonly consists of perforated plastic sheeting or extruded plastic netting (Tabler, 1994). Temporary fences may be preferred to trap snow in wetland basins as they can be easily dismantled during snow free periods.

Vegetative barriers can range in size from short stature grass strips to tall tree rows. For the purpose of increasing the water supply to wetlands, larger vegetative barriers such as tree rows may be unfavorable because they require a significant amount of time to get established, are more permanent than other snow barriers (Shaw, 1988), may consume water that would otherwise be available to the wetland (Siddoway, 1970; Greb and Black, 1961a), and may not be good ecological fits in natural grassland habitats (Kelsey and others, 2006). Grass strips provide a better option as a vegetative barrier for the purpose of trapping snow in wetland basins. Strips of sorghum (Sorghum bicolor; Greb and Black, 1961b), sudangrass (Sorghum x drummondii; Greb and others, 1965), tall wheatgrass (Thinopyron ponticum; Black and Siddoway, 1971), corn (Zea mays; Tabler, 1994), and other species have been used as vegetative barriers to trap snow. The method for creating a grass strip is similar for each species; a row or multiple rows of grass are planted perpendicular to the prevailing wind. This type of vegetative barrier can also be obtained by leaving strips in mowed or cultivated vegetative cover (Pomeroy and Gray, 1995). Reducing vegetation height and increasing surface roughness is effective for increasing snow movement and water yield on sagebrush rangelands. Snow accumulation was increased by mowing sagebrush on the windward side of a ridge (Sturges and Tabler, 1981). This allowed for more snow to be transported across the ridge and to become trapped on the leeward side. Sturges and Tabler (1981) estimated that this method could provide an average of 63 percent of the water needed to fill a 12,200-cubic-meter stock pond; however, most of the water was lost to seepage and did not reach the intended stock pond. Strips of crested wheatgrass among sagebrush rangeland doubled on-site snow retention and improved site productivity by increasing surface roughness and trapping more snow (Sturges and Tabler, 1981).

When considering the design of a snow fence or vegetation barrier, height, porosity, and placement need to be considered. Whether using vegetation or artificial barriers, the principles are the same. To capture the largest drift possible, barriers should be placed perpendicular to the prevailing wind, and have a porosity of 40-60 percent. Artificial barriers should have a gap of 10-15 percent of the fence's height at the bottom in order to keep the fence from becoming buried (Pomeroy and Gray, 1995). Snow barriers should also extend beyond the area of interest by at least 25 degrees Fahrenheit on both sides to account for drift loss because of end effects (Tabler and Schmidt, 1986).

The largest snowdrift that a barrier can sustain is referred to as the equilibrium drift. The length of a leeward equilibrium drift will be at maximum 35 times the barrier height with a maximum depth 1.2 times the barrier height (fig. 8). A snow barrier may also create a drift on the windward side of the fence. The windward equilibrium drift will have a length about 15 times the barrier height with a maximum depth 0.5 times the barrier height (Pomeroy and Gray, 1995). The dimensions reported are for horizontal-slat fence designs with 50 percent porosity on level terrain; other snow barrier designs may have slightly different equilibrium drift dimensions. Also, topographic depressions already act as snow catchments; thus, adding a snow barrier will only enhance the amount of snow caught (Jairell and Schmidt, 1990; Tabler, 1975).

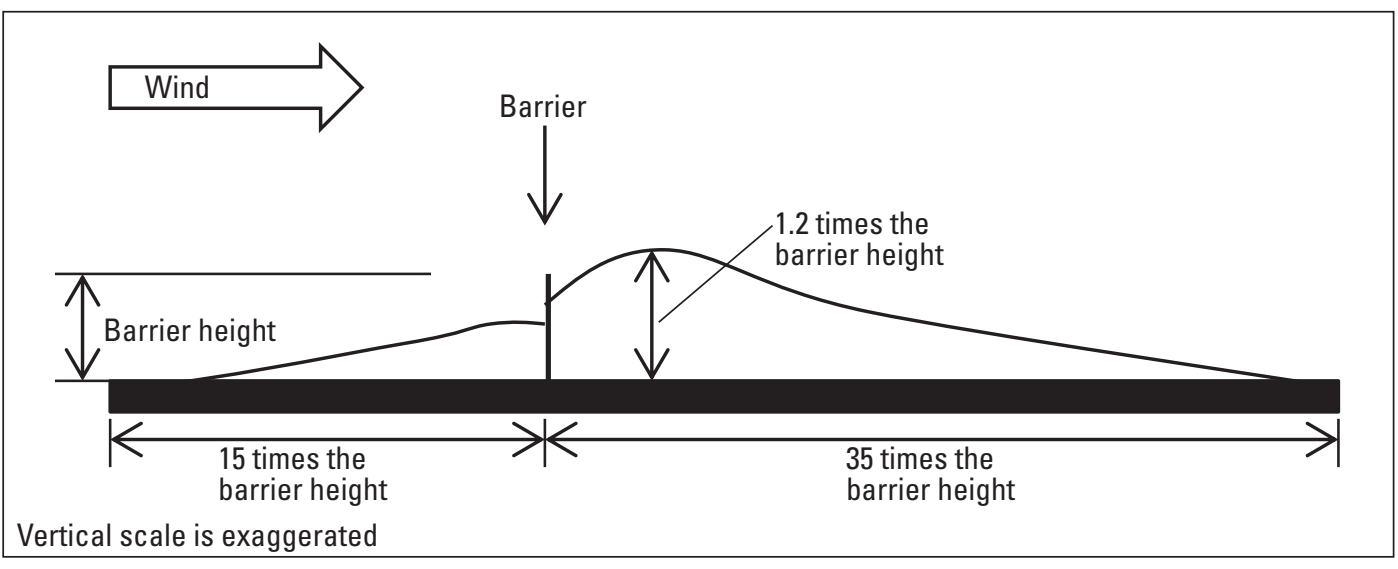

Modified from Pomeroy and Gray, 1995

Figure 8. Equilibrium drift geometry for a horizontal slat fence with 50 percent porosity placed on level terrain. 
Research on snow barriers has primarily focused on increasing streamflow (Sturges, 1992; Tabler and Sturges, 1986; Harrison, 1986; Cooley and others, 1981), increasing soil moisture (Ries and Power, 1981; Black and Siddoway, 1971; Greb and Black, 1961b), and protecting highways from snowstorms and snow drifting (Tabler, 1973). Currently, there has been no research on the effects of snow fences on wetland water levels in the northern prairie region. However, some conclusions may be made from studies researching the effects of snow fences on livestock pond and irrigation reservoir water levels. When placed on the windward side of a channel that flowed into an irrigation reservoir, snow fencing increased water yield by an average of 54 cubic meters per year (Sturges and Tabler, 1981). Constructing snow fences on the windward side of livestock ponds greatly increased the volume of snow captured over the pond (Sturges, 1989). However, much of the water was unavailable to cattle during the grazing season because of large amounts of seepage. Thus, it is important to consider soil drainage class when trying to increase water input into livestock ponds and natural wetlands. Soil permeability rates should fall below the low end of the poor drainage class when trying to increase water levels for an extended period of time (Sturges, 1989). Snow fences were most effective when placed leeward of the pond with an embankment on the windward side of the pond (Jairell and Tabler, 1985). This configuration could produce 5.8 times more snow volume near the pond, whereas a configuration with both the snow fence and embankment located on the leeward side of the pond increased volume of snow by 5.6 times (fig. 9).

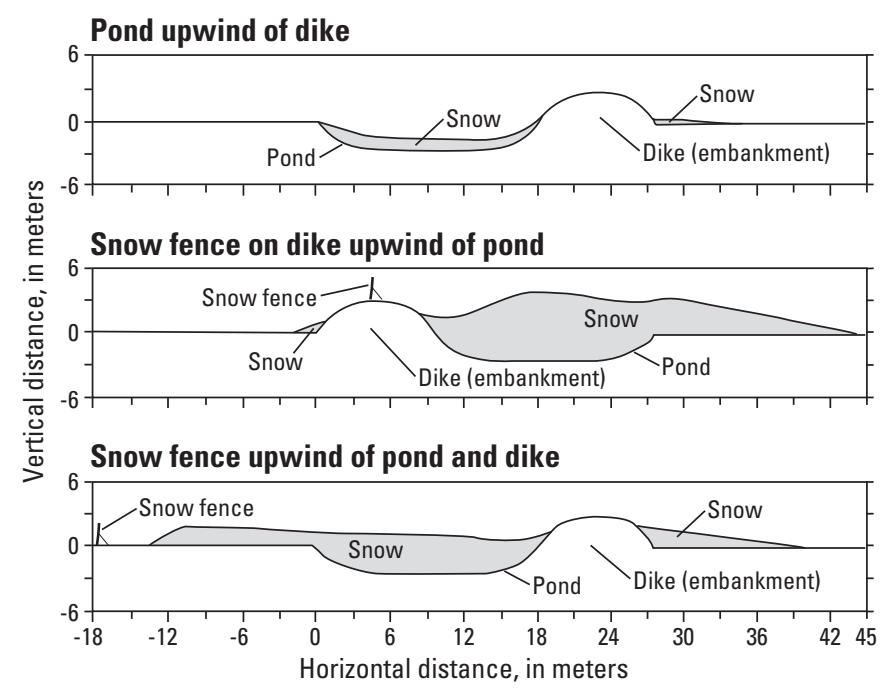

Modified from Jairell and Schmidt, 1990

Figure 9. Cross section of 1:30 model livestock pond.
Prairie pothole wetlands naturally catch snow because of their topography and vegetation (Fang and Pomeroy, 2009; Tabler, 1975). Topography and vegetation alter surface roughness and redirect wind; thus, topography and vegetation affect snow distribution. For example, a leeward slope will accumulate much larger volumes of snow than the windward slope if vegetation is absent (Pomeroy and Gray, 1995; Steppuhn, 1981). Additionally, increases in surface roughness caused by vegetation manipulation increased the amount of snow captured on the landscape (Pomeroy and Gray, 1995; Steppuhn, 1981). Thus, tall wetland vegetation can act as a natural snow barrier. This effect could be enhanced by reducing surrounding upland vegetation height by grazing or burning. By reducing upland vegetation height, more snow will be free to be transported into wetland basins. Therefore, grazing and burning should not only affect a catchment's hydrology in terms of runoff events, but also how the catchment will capture snow. In fact, for farmers in the northern plains to burn off wetland vegetation in the fall so the vegetation will not catch blowing snow is common practice. This reduces the amount of flooding in a farmer's field and may even allow for the wetland basin to be cultivated if conditions are dry enough.

Wetland water levels are affected by vegetation in the surrounding catchment. Water levels for 10 cultivated wetlands were monitored from 1968 to 1997 (van der Kamp and others, 1999). During 1980-83, five of the wetland catchments had been converted to smooth bromegrass and alfalfa cover, and the other five remained in cultivation. During 1968-80, water-level fluctuations were similar for all ten wetlands. However, during 1980-97 the water levels of the five wetlands that had their catchments converted began to drop and became dry after a few years, and the wetlands that remained in cultivation remained wet. The converted wetlands remained dry except when overland flow from other wetlands took place during periods of increased precipitation.

Possible mechanisms behind the drying of the wetlands with converted catchments were evaluated (van der Kamp and others, 2003). Snowmelt runoff was greatly reduced for the wetlands with catchments of smooth bromegrass and alfalfa. Under complete grass cover, snow was trapped in the uplands because of the standing grass, whereas snow in the cultivated fields was blown off the uplands and caught by the standing vegetation in the wetland basin. Also, snowmelt was more likely to infiltrate into the soil and be lost to evapotranspiration because of the grassed soil having a more developed macropore structure. Infiltrability of the frozen cultivated soil fell below the rate at which the snow melted, whereas the infiltrability of the frozen grassed soil was typically higher than the rate at which the snow melted. The data show that changes in land cover can greatly affect how a landscape captures snow and have significant impacts on the hydrology of wetlands within the landscape. 


\section{Conclusions}

In addition to supporting a variety of wildlife, Prairie Pothole Region (PPR) wetlands provide other benefits to society that include water-quality improvement, flood control, groundwater recharge, carbon sequestration, recreation, and aesthetics. Despite the multiple benefits of having properly functioning wetlands on the landscape, many wetlands in the PPR have been filled, drained, or destroyed to facilitate crop production. Remaining wetlands are being affected from the cumulative effects of hydrologic and land-use alterations within watersheds. How the region's remaining wetlands will respond to changing climate conditions resulting from increased levels of carbon dioxide in the atmosphere is of great concern.

Water conditions in PPR wetlands are sensitive to changes in climate because of the dependence of wetland water levels and hydroperiods on atmospheric interactions. Temperatures in the PPR are likely to increase between 3.7 and 6.1 degrees Celsius $\left({ }^{\circ} \mathrm{C}\right)$ by the end of the century. Increased temperatures will result in increased water losses from wetlands that correspond to increases in evapotranspiration and evaporative demand. Precipitation is harder to model because of its great regional variability. Nevertheless, future precipitation in the PPR is expected to increase by 10 percent and has already increased by an estimated 9 percent during the previous century. In addition to changes in average temperatures and precipitation, the frequency and severity of drought and deluge conditions, which are primary drivers of PPR wetland productivity, are expected to intensify under a climate affected by increased levels of atmospheric greenhouse gases.

Models of PPR wetlands under scenarios of climate change indicate that the wetlands will likely spend more time in a condition of low productivity when the wetlands are dry and (or) choked by stands of emergent cover. Temperature increases alone have potential to shift favorable water and vegetative cover conditions to the northern and eastern edges of the PPR. Increased precipitation in conjunction with temperature increases can have a counterbalancing effect, but only substantial increases in precipitation can ameliorate the effects of elevated temperatures. Model simulations indicate that a 5-7 percent precipitation increase would be needed to counteract each $1{ }^{\circ} \mathrm{C}$ temperature increase. However, interpretation of studies exploring the effects of climate change on PPR wetlands water dynamics are complicated by great spatial and temporal variation in wetland dynamics across the region. Even so, development of mitigation strategies that would deal with potential negative effects resulting from a changing climate would seem highly prudent.

Studies of grassland management effects on water runoff, infiltration, and snow accumulation indicated that the effects of climate change might be mitigated through the targeted use of land-use practices. Grazing by livestock can cause changes in the hydrology of a watershed through the removal of plant cover and the physical action of animal hooves on vegetation and soils. By altering runoff, infiltration, and upland evapotranspiration rates, grazing can have a significant effect on prairie pothole wetland water levels and hydroperiods. Prescribed burning can also cause an increase in runoff volume by decreasing infiltration, and prescribed burning on slopes less than 20 percent may not significantly increase erosion. Model runs indicate that spring burns can increase average annual water levels by about 20 percent compared to the unmanaged native grasslands (Voldseth and others, 2007).

Snowmelt is the most crucial water supply for prairie pothole wetlands, accounting for as much as $80-85$ percent of the total surface runoff for prairie habitats (LaBaugh and others, 1998). Snow is transported across the landscape by wind action until it forms drifts because of vegetation, topography, or manmade barriers. Snow accumulation can be managed with the use of manmade or vegetative barriers. Prairie pothole wetlands naturally catch snow because of the wetland topography and vegetation. Topography and vegetation alter surface roughness and redirect wind, and thus affect snow distribution. Increases in surface roughness caused by vegetation manipulation can increase the amount of snow captured on the landscape. Thus, tall wetland vegetation can act as a natural snow barrier. Reducing surrounding upland vegetation using grazing or burning could enhance this snow capturing effect. By reducing the upland vegetation, more snow will be free to be transported into wetland basins. Therefore, grazing and burning should not only affect a catchments hydrology in terms of runoff events but also how the catchment will capture snow.

Future effects of a changing climate on prairie pothole wetland water levels and hydroperiods can be difficult to quantify because of naturally high variability of the region's climate and ecosystems. However, upland management appears to indicate significant opportunities to mitigate potential effects. Grassland management can greatly affect how water infiltrates into soils, runs off following precipitation events, evaporates into the atmosphere, and distributes across the landscape during the winter. Thus, well planned and implemented grazing, burning, and snow management programs that focused on increasing water inputs to wetlands have great potential to mitigate some of the effects of a warming climate. The ability to target management actions to increase water inputs into wetlands will be especially important in areas where increases in precipitation are not enough to counteract the effects of increased evapotranspiration and thereby maintain water conditions in wetlands at desired levels. To further the ability to take advantage of mitigation opportunities, additional research is needed that focuses on refining upland management for the betterment of upland plant and animal communities and also the embedded wetland ecosystems. Additionally, more research is needed that focuses on verifying the model results and research conclusions discussed in this report. 


\section{References Cited}

Badh, A., Akyuz, A., Vocke, G., and Mullins, B., 2009, Impact of climate change on the growing seasons in select cities of North Dakota, United States of America: International Journal of Climate Change, Impacts and Responses, v. 1, p. $105-117$.

Ballard, T., Seager, R., Smerdon, J., Cook, B., Ray, A.J., Rajagopalan, B., Kushnir, Y., Nakamura, J., and Henderson, N., 2014, Hydroclimate variability and change in the Prairie Pothole Region, the "Duck Factory" of North America: Earth Interactions, v. 18, p. 1-28.

Batt, B.D.J., Anderson, M.G., Anderson, C.D., and Caswell, F.D., 1989, The use of prairie potholes by North American ducks, in van der Valk, A.G., ed., Northern Prairie Wetlands: Ames, Iowa, Iowa State University Press, p. 204-227.

Benavides-Solorio, J., and MacDonald, L.H., 2001, Post-fire runoff and erosion from simulated rainfall on small plots, Colorado Front Range: Hydrological Processes, v. 15, p. 2931-2952.

Black, A.L., and Siddoway, F.H., 1971, Tall wheatgrass barriers for soil erosion control and water conservation: Journal of Soil and Water Conservation, v. 26, p. 107-111.

Blackburn, W.H., 1983, Livestock grazing impacts on watersheds: Rangelands, v. 5, p. 123-125.

Bremer, D.J., and Ham, J.M., 1999, Effect of spring burning on the surface energy balance in a tallgrass prairie: Agricultural and Forest Meteorology, v. 97, p. 43-54.

Bremer, D.J., Auen, L.M., Ham, J.M., and Owensby, C.E., 2001, Evapotranspiration in a prairie ecosystem - Effects of grazing by cattle: Agronomy Journal, v. 93, p. 338-348.

Chanasyk, D.S., Mapfumo, E., and Willms, W., 2003, Quantification and simulation of surface runoff from fescue grassland watersheds: Agricultural Water Management, v. 59, p. 137-153.

Cooley, K.R., Huber, A.L., Robertson, D.C., and Zuzel, J.F., 1981, Effects of snowdrift management on rangeland runoff, in Annual Western Snow Conference, 49th, St. George, Utah, 1981, Proceedings: St. George, Utah, Western Snow Conference, p. 55-64.

Conly, F.M., and Van der Kamp, G., 2001, Monitoring the hydrology of Canadian prairie wetlands to detect the effects of climate change and land use changes: Environmental Monitoring and Assessment, v. 67, 195-215.
Covich, A.P., Fritz, S.C., Lamb, P.J., Marzolf, R.D., Matthews, W.J., Poiani, K.A., Prepas, E.E., Richman, M.B., and Winter, T.C., 1997, Potential effects of climate change on aquatic ecosystems of the Great Plains of North America: Hydrological Processes, v. 11, p. 993-1021.

Dahl, T.E., 1990, Wetlands losses in the United States 1780's to 1980's: Washington, D.C., U.S. Fish and Wildlife Service, $13 \mathrm{p}$.

Dahl, T.E., 2014, Status and trends of prairie wetlands in the United States 1997 to 2009: Washington, D.C., U.S. Fish and Wildlife Service, 67 p.

DeBano, L.F., 2000, The role of fire and soil heating on water repellency in wildland environments-A review, Journal of Hydrology, v. 231, p. 195-206.

DeBano, L.F., Neary, D.G., and Ffolliott, P.F., 1998, Fire's effects on ecosystems: New York, John Wiley \& Sons, Inc.

Dyke, A.S., and Prest, V.K., 1987, Late Wisconsinan and Holocene history of the Laurentide ice sheet: Geographie Physique et Quaternaire, v. 41, p. 237-264.

Euliss, N.H., Jr., and Smith, L.M., 2010, Ecosystem process and the hemi-marsh concept_Clarifying principles for wetland management: National Wetlands Newsletter, v. 32, p. 23-24.

Euliss, N.H., Jr., Wrubleski, D.A., and Mushet, D.M., 1999, Wetlands of the prairie pothole region-Invertebrate species composition, ecology, and management, in Batzer, D., Rader, R.B., and Wissinger, S.A., eds., 1999, Invertebrates in freshwater wetlands of North America-Ecology and Management: New York, John Wiley and Sons, Inc., p. $471-514$.

Ffolliott, P.F., and Thorud, D.B., 1977, Water yield improvement by vegetation management: Journal of the American Water Resources Association, v. 13, p. 563-571.

Frank, D.A., and Inouye, R.S., 1994, Temporal variation in actual evapotranspiration of terrestrial ecosystemsPatterns and ecological implications: Journal of Biogeography, v. 21, p. 401-411.

Garbrecht, J.D., and Rossel, F.E., 2002, Decade-scale precipitation increase in Great Plains at the end of 20th century: Journal of Hydrologic Engineering, v. 7, p. 64-75.

Gleason, R.A., Laubhan, M.K., and Euliss, N.H., Jr., eds., 2008, Ecosystem services derived from wetland conservation programs in the United States prairie pothole region with an emphasis on the U.S. Department of Agriculture Conservation Reserve and Wetlands Reserve Programs: U.S. Geological Survey Professional Paper 1745, 58 p. 
Gray, D.M., and Landine, P.G., 1988, An energy-budget snowmelt model for the Canadian Prairies: Canadian Journal of Earth Sciences, v. 25, p. 1292-1303.

Gray, D.M., Norum, D.I., and Dyck, G.E., 1970, Densities of prairie snowpacks, in Annual Western Snow Conference, 38th, Victoria, British Columbia, 1970, Proceedings: Victoria, British Columbia, Western Snow Conference, p. 24-30.

Greb, B.W., and Black, A.L., 1961a, Effects of windbreak plantings on adjacent crops: Journal of Soil and Water Conservation, v. 16, p. 223-227.

Greb, B.W., and Black, A.L., 1961b, New strip cropping pattern saves moisture for dryland: Crops and Soils, v. 13, p. 23.

Greb, B.W., Mickelson, R.H., and Hinze, G.O., 1965, Conservation research at the Central Great Plains Field Station: Northern Plains Branch, Soil and Water Conservation Research Division, Agricultural Research Service, U.S. Department of Agriculture, misc. leaflet.

Hanson, C.L., Kuhlman, A.R., Erickson, C.J., and Lewis, J.K., 1970, Grazing effects on runoff and vegetation on western South Dakota rangeland: Journal of Range Management, v. 23 , p. $418-420$.

Hanson, C.L., and Lewis, J.K., 1978, Winter runoff and soil water storage as affected by range condition: Proceedings of the First International Rangeland Congress, Denver, Colo., p. 284-287.

Harrison, W., 1986, Effects of snow fences on the snowpack of a block mountain in Otago: Journal of Hydrology New Zealand, v. 25, p. 18-40.

Helvey, J.D., 1980, Effects of a north central Washington wildfire on runoff and sediment production: Journal of the American Water Resources Association, v. 16, p. 627-634.

Henny, C.J., Anderson, D.R., and Pospahala, R.S., 1972, Aerial Surveys of Waterfowl Production in North America, 1955-71: U.S. Fish and Wildlife Service Special Scientific Report, Wildlife 160, 48 p.

Hester, J.W., Thurow, T.L., and Taylor, C.A., 1997, Hydrologic characteristics of vegetation types as effected by prescribed burning: Journal of Range Management, v. 50, p. 199-204.

Holecheck, J.L., 1981, Livestock grazing impacts on public lands-A viewpoint: Journal of Range Management, v. 34, p. 251-254.
Intergovernmental Panel on Climate Change, 2013, Climate Change 2013-The Physical Science Basis, in Stocker, T.F., Qin, D., Plattner, G.K., Tignor, M., Allen, S.K., Boschung, J., Nauels, A., Xia, Y., Bex, V., and Midgley, P.M., eds., Contribution of Working Group I to the fifth assessment report of the Intergovernmental Panel on Climate Change: Cambridge, United Kingdom, and New York, Cambridge University Press, 1535 p.

Jairell, R.L., and Schmidt, R.A., 1990, Snow fencing near pit reservoirs to improve water supplies, in Annual Western Snow Conference, 58th, Sacramento, Calif., 1990, Proceedings: Sacramento, Calif., Western Snow Conference, p. 156-159.

Jairell, R.L., and Tabler, R.D., 1985, Model studies of snowdrifts formed by livestock shelters and pond embankments, in Annual Western Snow Conference, 53th, Boulder, Colo., 1985, Proceedings: Boulder, Colo., Western Snow Conference, p. 167-170.

Johnson, W.C., Boettcher, S.E., Poiani, K.A., and Guntenspergen, G., 2004, Influence of weather extremes on the water levels of glaciated prairie wetlands: Wetlands, v. 24 , p. 385-398.

Johnson, W.C., Millett, B.V., Gilmanov, T., and Naugle, D.E., 2005, Vulnerability of northern prairie wetlands to climate change: BioScience, v. 55, p. 863-872.

Johnson, W.C., Werner, B., Guntenspergen, G.R., Voldseth, R.A., Millett, B., Naugle, D.E., Tulbure, M., Carroll, W.H., Tracy, J., and Olawsky, C., 2010, Prairie wetland complexes as landscape functional units in a changing climate: BioScience, v. 60, p. 128-140.

Kantrud, H.A., Krapu, G.L., and Swanson, G.A., 1989, Prairie basin wetlands of the Dakotas - A community profile: Washington, D.C., U.S. Fish and Wildlife Service Biological Report 85, 111 p.

Kelsey, K.W., Naugle, D.E., Higgins, K.F., and Bakker, K.K., 2006, Planting trees in prairie landscapes - Do the ecological costs outweigh the benefits: Natural Areas Journal, v. 26, p. 254-260.

Knutsen, G.A., and Euliss, N.H., 2001, Wetland restoration in the prairie pothole region of North America-A literature review: U.S. Geological Survey, Biological Resources Division, Biological Science Report, USGS/BRD/BSR2001-0006, 54 p.

Koelliker, J.K., and Duell, A.B., 1990, Effect of burning on surface hydrology of tallgrass prairie, in Winter Meeting, Chicago, Ill., 1990, Proceedings: Chicago, Ill., American Society of Agricultural Engineers, Paper no. 902568, 11 p. 
LaBaugh, J.W., Winter, T.C., and Rosenberry, D.O., 1998, Hydrologic functions of prairie wetlands: Great Plains Research, v. 8, p. 17-37.

Larson, D.L., 1995, Effects of climate on numbers of northern prairie wetlands: Climatic Change, v. 30, p. 169-180.

Leitch, J.A., 1989, Politicoeconomic overview of prairie potholes, in van der Valk, A.G., ed., Northern Prairie Wetlands: Ames, Iowa, Iowa State University Press, p. 2-14.

Leitch, J.A., 1996, Empirical valuation of prairie potholesFive case studies: Great Plains Research, v. 6, p. 25-39.

Manabe, S., and Wetherald, R.T., 1987, Large-scale changes of soil wetness induced by an increase in atmospheric carbon dioxide: Journal of the Atmospheric Sciences, v. 44, p. 1211-1236.

Meehl, G.A., Tebaldi, C., and Nychka, D., 2004, Changes in frost days in simulations of twentyfirst century climate: Climate Dynamics, v. 23, p. 495-511.

Millett, B., Johnson, W.C., and Guntenspergen, G., 2009, Climate trends of the North American prairie pothole region 1906-2000: Climatic Change, v. 93, p. 243-267.

Murphy, J.M., and Mitchell, J.F.B., 1995, Transient response of the Hadley centre coupled ocean-atmosphere to increasing carbon dioxide: Journal of Climate, v. 8 , p. 36-80.

Naeth, M.A., and Chanasyk, D.S., 1996, Runoff and sediment yield under grazing in foothills fescue grasslands of Alberta: Journal of the American Water Resources Association, v. 32, p. 89-95.

Neary, D.G., 1995, Effects of fire on water resources-A review: Hydrology and Water Resources in Arizona and the Southwest, v. 22-25, p. 45-53.

Niemuth, N.D., Fleming, K.K., and Reynolds, R.E., 2014, Waterfowl conservation in the US Prairie Pothole RegionConfronting the complexities of climate change: Public Library of Science One, v. 9, e100034.

Niemuth, N.D., Wangler, B., and Reynolds, R.E., 2010, Spatial and temporal variation in wet area of wetlands in the Prairie Pothole Region of North Dakota and South Dakota: Wetlands, v. 30, p. 1053-1064.

Ojima, D.S., Lackett, J.M., and the Central Great Plains Steering Committee and Assessment Team, 2002, Preparing for a changing climate-The potential consequences of climate variability and change, Central Great Plains: Report for the U.S. Global Change Research Program, Colorado State University, $103 \mathrm{p}$.
Ouyang, Z., Becker, R., Shaver, W., and Chen, J., 2014, Evaluating the sensitivity of wetlands to climate change with remote sensing techniques: Hydrological Processes, v. 28 , p. $1703-1712$.

Palmer, W.C., 1965, Meteorological drought: U.S. Weather Bureau, Research Paper 45, 58 p.

Poiani, K.A., and Johnson, W.C., 1991, Global warming and prairie wetlands: BioScience, v. 41, p. 611-618.

Poiani, K.A., and Johnson, W.C., 1993a, A spatial simulation model of hydrology and vegetation dynamics in semipermanent prairie wetlands: Ecological Applications, v. 3, p. 279-293.

Poiani, K.A., and Johnson, W.C., 1993b, Potential effects of climate change on a semi-permanent prairie wetland: Climatic Change, v. 24, p. 213-232.

Poiani, K.A., Johnson, W.C., and Kittel, T.G.F., 1995, Sensitivity of a prairie wetland to increased temperature and seasonal precipitation changes: Water Resources Bulletin, v. 31, p. 283-294.

Poiani, K.A., Johnson, W.C., Swanson, G.A., and Winter, T.C., 1996, Climate change and northern prairie wetlandsSimulations of long-term dynamics: Limnology and Oceanography, v. 41, p. 871-881.

Pomeroy, J.W., and Gray, D.M., 1995, Snowcover accumulation, relocation, and management: Saskatoon, Canada, National Hydrology Research Institute Science Report No. 7, 144 p.

Ries, R.E., and Power, J.F., 1981, Increased soil water storage and herbage production from snow catch in North Dakota: Journal of Range Management, v. 34, p. 485-488.

Robichaud, P.R., and Waldrop, T.A., 1994, A comparison of surface runoff and sediment yields from low- and highseverity site preparation burns: Journal of the American Water Resources Association, v. 30, p. 27-34.

Shaw, D.L., 1988, The design and use of living snow fences in North America: Agriculture, Ecosystems and Environment, v. 22, p. 351-362.

Shjeflo, J.B., 1968, Evapotranspiration and the water budget of prairie pothole in North Dakota: U.S. Geological Survey Professional Paper 585-B, 49 p.

Siddoway, F.H., 1970, Barriers for moisture conservation and wind erosion control in the Great Plains: Journal of Soil and Water Conservation, v. 25, p. 180-184.

Smith, A.G., Stoudt, J.H., and Gallop, J.B., 1964, Prairie potholes and marshes, in J.P. Linduska, ed., Waterfowl Tomorrow: U.S. Government Printing Office, Washington, D.C., p. 39-50. 
Sorenson, L.G., Goldberg, R., Root, T.L., and Anderson, M.G., 1998, Potential effects of global warming on waterfowl populations breeding in the Northern Great Plains: Climatic Change, v. 40, p. 343-369.

Steppuhn, H., 1981, Snow and agriculture, in Gray, D.M., and Male, D.H., eds., Handbook of Snow-Principles, Processes, Management and Use: Ontario, Canada, Pergamon Press Canada Ltd., p. 60-125.

Stewart, R.E., and Kantrud, H.A., 1971, Classification of natural ponds and lakes in the glaciated prairie region: Washington, D.C., Bureau of Sport Fisheries and Wildlife, Resource Publication 92, $57 \mathrm{p}$.

Sturges, D.L., and Tabler, R.D., 1981, Management of blowing snow on sagebrush rangelands: Journal of Soil and Water Conservation, v. 36, p. 287-292.

Sturges, D.L., 1989, Evaporation and seepage from a livestock reservoir equipped with a snow fence for water recharge, in Annual Western Snow Conference, 57th, Fort Collins, Colo., 1989, Proceedings: Fort Collins, Colo., Western Snow Conference, p. 9-20.

Sturges, D.L., 1992, Streamflow and sediment transport responses to snow fencing a rangeland watershed: Water Resources Research, v. 28, p. 1347-1356.

Swanson, G.A., Euliss, N.H., Hanson, B.A., and Mushet, D.M., 2003, Dynamics of a prairie pothole wetland complex-Implication for wetland management, in Winter T.C., ed., Hydrological, Chemical, and Biological Characteristics of a Prairie Pothole Wetland Complex under Highly Variable Climate Conditions-The Cottonwood Lake Area, East-Central North Dakota: U.S. Geological Survey Professional Paper 1675, p. 55-94.

Tabler, R.D., 1973, New snow fence design controls drifts, improves visibility, reduces road ice, in Annual Transportation Engineering Conference, 46th, Denver, Colo., 1973, Proceedings: Denver, Colo., University of Colorado, p. 16-27.

Tabler, R.D., 1975, Predicting profiles of snowdrifts in topographic catchments, in Annual Western Snow Conference, 43rd, Coronado, Calif., 1975, Proceedings: Coronado, Calif., Western Snow Conference, p. 87-97.

Tabler, R.D., 1991, Snow fence guide: Washington, D.C., Strategic Highway Research Program, National Research Council, No. SHRP-W/FR-91-106, 61 p.

Tabler, R.D., 1994, Design guidelines for the control of blowing and drifting snow: Washington, D.C., Strategic Highway Research Program, National Research Council, No. SHRP-H-381, 364 p.
Tabler, R.D., and Schmidt, R.A., 1986, Snow erosion, transport, and deposition in relation to agriculture: Proceedings of the Symposium on Snow Management for Agriculture, Great Plains Agricultural Council Publication No. 120 , p. $12-58$.

Tabler, R.D., and Sturges, D.L., 1986, Watershed test of a snow fence to increase streamflow-Preliminary results: Proceedings of the Cold Regions Hydrology Symposium, v. TPS-86-1, p. 53-61.

Tiner, R.W., 1984, Wetlands of the United States-Current status and recent trends: Washington, D.C., U.S. Fish and Wildlife Service, $59 \mathrm{p}$.

Tiner, R.W., 2003, Geographically isolated wetlands of the United States: Wetlands, v. 23, p. 494-516.

Turner, B.C., Hochbaum, G.S., Caswell, F.D., and Nieman, D.J., 1987, Agricultural impacts on wetland habitats on the Canadian Prairies: Transactions of the North American Wildlife and Natural Resources Conference, v. 52 , p. 206-215.

van der Kamp, G.W., Stolte, W.J., and Clark, R.G., 1999, Drying out of small prairie wetlands after conversion of their catchments from cultivation to permanent brome grass: Hydrological Sciences Journal, v. 44, p. 387-397.

van der Kamp, G.W., Hayashi, M., Gallén, D., 2003, Comparing the hydrology of grassed and cultivated catchments in the semi-arid Canadian prairies: Hydrological Processes, v. 17, p. 559-575.

van der Valk, A.G., and Davis, C.B., 1978, The role of seed banks in the vegetation dynamics of prairie glacial marshes: Ecology, v. 59, p. 322-335.

Voldseth, R.A., Johnson, W.C., Gilmanov, T., Guntenspergen, G.R., and Millett, B.V., 2007, Model estimation of landuse effects on water levels of Northern Prairie wetlands: Ecological Applications, v. 17, p. 527-540.

Voldseth, R.A., Johnson, W.C., Guntenspergen, G.R., Gilmanov, G.R., and Millett, B.V., 2009, Adaptation of farming practices could buffer effects of climate change on northern prairie wetlands: Wetlands, v. 29, p. 635-647.

Werner, B.A., Johnson, W.C., and Guntenspergen, G.R., 2013, Evidence for 20th century climate warming and wetland drying in the North American Prairie Pothole Region: Ecology and Evolution, v. 3, p. 3471-3482.

Wilen, B.O., and Bates, M.K., 1995, The U.S. Fish and Wildlife Service's National Wetlands Inventory project: Vegetatio, v. 118, p. 153-169. 
Winter, T.C., 1989, Hydrologic studies of wetlands in the northern prairie, in van der Valk, A.G., ed., Northern Prairie Wetlands: Ames Iowa, Iowa State University Press, p. 16-54.

Winter, T.C., and Rosenberry, D.O., 1998, Hydrology of prairie pothole wetlands during drought and deluge-A 17-year study of the Cottonwood Lake Wetland Complex in North Dakota in the perspective of longer term measure and proxy hydrological records: Climatic Change, v. 40, p. 189-209.

Wright, H.A., Churchill, F.M., and Stevens, C., 1976, Effect of prescribed burning on sediment, water yield, and water quality from dozed juniper lands in central Texas: Journal of Range Management, v. 29, p. 294-298.

Zhang, H., Huang, G.H., Wang, D., and Zhang, X., 2011, Uncertainty assessment of climate change impacts on the hydrology of small prairie wetlands: Journal of Hydrology, v. 396, p. 94-103.

Zhang, X., Vincent, L.A., Hogg, W.D., and Niitsoo A., 2000, Temperature and precipitation trends in Canada during the 20th Century: Atmosphere-Ocean, v. 38, p. 395-429.
Publishing support provided by:

Rolla and Sacramento Publishing Service Centers

For more information concerning this publication, contact: Director, USGS Northern Prairie Wildlife Research Center 8711 37th Street Southeast Jamestown, North Dakota 58401

(701) 253-5500

Or visit the Northern Prairie Wildlife Research Center Web site at: http://npwrc.usgs.gov/ 


